\title{
TRADEOFFs in climate effects through aircraft routing: forcing due to radiatively active gases
}

F. Stordal $^{1,2}$, M. Gauss ${ }^{2}$, G. Myhre ${ }^{2}$, E. Mancini ${ }^{3}$, D. A. Hauglustaine ${ }^{4}$, M. O. Köhler ${ }^{5}$, T. Berntsen ${ }^{2}$, E. J. G. Stordal ${ }^{1}$, D. lachetti ${ }^{3}$, G. Pitari ${ }^{3}$, and I. S. A. Isaksen ${ }^{2}$

${ }^{1}$ Norwegian Institute for Air Research (NILU), Norway

${ }^{2}$ Department of Geosciences, University of Oslo, Norway

${ }^{3}$ University of L'Aquila, Italy

${ }^{4}$ Institut Pierre Simon Laplace (IPSL), Laboratoire des Sciences du Climat et de l'Environnement (LSCE), France

${ }^{5}$ University of Cambridge, UK

Received: 17 July 2006 - Accepted: 6 October 2006 - Published: 20 October 2006

Correspondence to: F. Stordal (Frode.Stordal@geo.uio.no)

TRADEOFFs in climate effects

through aircraft

routing

F. Stordal et al.

Title Page

Abstract

Introduction

Conclusions

References

Tables

Figures

14

$\rightarrow$

4

Back

Close 


\section{Abstract}

We have estimated impacts of alternative aviation routings on the radiative forcing. Changes in ozone and $\mathrm{OH}$ have been estimated in four Chemistry Transport Models (CTMs) participating in the TRADEOFF project. Radiative forcings due to ozone and 5 methane have been calculated accordingly. In addition radiative forcing due to $\mathrm{CO}_{2}$ is estimated based on fuel consumption. Three alternative routing cases are investigated; one scenario assuming additional polar routes and two scenarios assuming aircraft cruising at higher $(+2000 \mathrm{ft})$ and lower $(-6000 \mathrm{ft})$ altitudes. Results from the base case in year 2000 are included as a reference. Taking first a steady state backward looking approach, adding the changes in the forcing from ozone, $\mathrm{CO}_{2}$ and $\mathrm{CH}_{4}$, the ranges of the models used in this work are -0.8 to -1.8 and 0.3 to $0.6 \mathrm{mWm}^{-2}$ in the lower ($6000 \mathrm{ft}$ ) and higher $(+2000 \mathrm{ft}$ ) cruise levels, respectively. In relative terms, flying $6000 \mathrm{ft}$ lower reduces the forcing by $5-10 \%$ compared to the current flight pattern, whereas flying higher, while saving fuel and presumably flying time, increases the forcing by about $2-3 \%$. Taking next a forward looking approach we have estimated the integrated forcing $\left(\mathrm{mWm}^{-2} \mathrm{yr}\right)$ over 20 and 100 years time horizons. The relative contributions from each of the three climate gases are somewhat different from the backward looking approach. The differences are moderate adopting 100 year time horizon, whereas under the 20 year horizon $\mathrm{CO}_{2}$ naturally becomes less important relatively. Thus the forcing agents impact climate differently on various time scales. Also, we have found significant differences between the models for ozone and methane. We conclude that we are not yet at a point where we can include non- $\mathrm{CO}_{2}$ effects of aviation in emission trading schemes. Nevertheless, the rerouting cases that have been studied here yield relatively small changes in the radiative forcing due to the radiatively active gases.

\section{ACPD}

6, 10733-10771, 2006

TRADEOFFs in climate effects

through aircraft routing

F. Stordal et al.

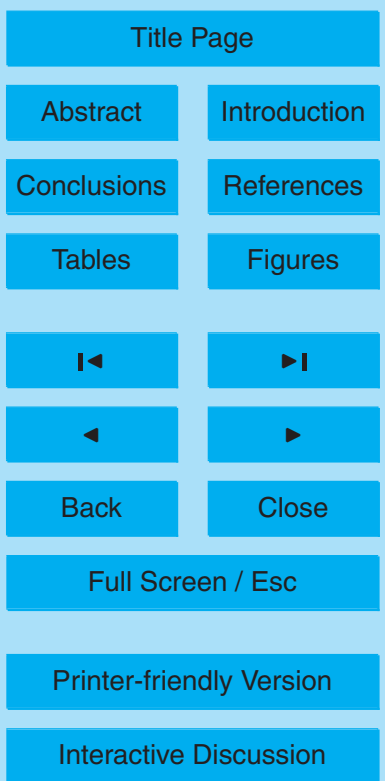




\section{Introduction}

Aircraft are known to yield impacts on climate in several ways, most significantly through emissions of gases that directly or indirectly impacts the levels of radiatively active gases, and through formation of condensation trails (contrails) and cirrus clouds.

5 Substantial effort has been made to quantify radiative forcings due to all these mechanisms (see e.g. IPCC, 1999; Sausen et al., 2005). Investigation and assessment of ways to reduce environmentally negative impacts, including contributions to climate change, have taken various paths. First, there have been several propositions to technological solutions of the problems (Rogers et al., 2002), e.g. by altering aircraft design 10 and configurations (Green, 2003; 2005; Akerman, 2005), or by using alternative fuel, for example liquid hydrogen (Marquart et al., 2001; Gauss et al., 2003; Svensson et al., 2004).

Second, various changes in operational practice have been proposed. In general, climate effects of aircraft are sensitive to where and when emissions take place, and 15 thus a few attempts have been made to break climate impacts down e.g. to certain parts of the year or of the day (Myhre and Stordal, 2001; Stuber et al., 2006). However, regarding changes in operations a main emphasis has been on studies of changing cruise levels. Formation of contrails depends on temperature and moisture of the ambient air. Thus aircraft cruise altitude is a main factor in determining contrail formation (e.g. Sausen et al., 1996; Schumann, 2005). The same is true for the transition of contrails into cirrus clouds (Mannstein et al., 2005). These effects have been estimated in recent model experiments (Williams et al., 2002; Fichter at al., 2005).

Aircraft emissions of $\mathrm{NO}_{\mathrm{x}}$ have a chemical impact on two radiatively active gases, namely ozone and methane (e.g. Grewe et al., 2002a, b; Dessens and Simon, 2002;

Liu et al., 2003; Stevenson et al., 2004). It is well known that the atmospheric chemistry impacting ozone and $\mathrm{OH}$ and thus methane depends on location (altitude as well as geographical location) and time (of the day and of the year). Further, ozone is (unlike methane) not long lived enough to be well mixed in the troposphere, making the ozone
TRADEOFFs in climate effects

through aircraft routing

F. Stordal et al.

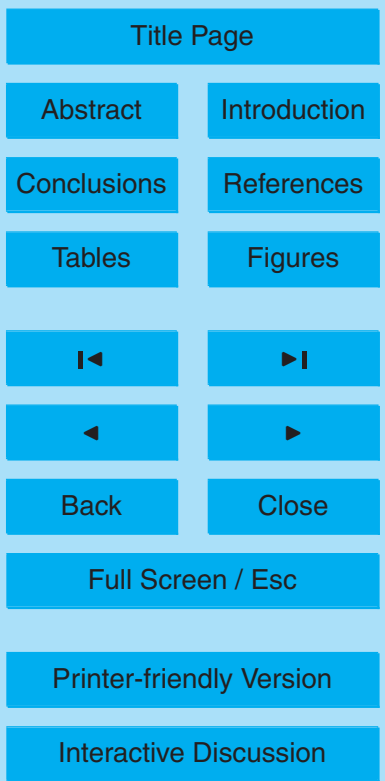


distribution even more sensitive to the location and time of aircraft emissions. Consequently, e.g. the altitude of aircraft $\mathrm{NO}_{\mathrm{x}}$ emissions impacts the chemical effects on both ozone and methane (Grewe et al., 2002c; Williams et al., 2003), whereas in the case of ozone there is an additional dependence on the altitude distribution of ozone itself

5 (Hansen et al., 1997; Forster and Shine, 1997; IPCC, 2001). The vertical distribution is important in defining the radiative impacts of ozone changes. Changes in the vertical routing patterns can therefore potentially be used to minimize climate impacts of aircraft traffic. Likewise, changes in geographical flight patterns will influence the impacts on ozone and methane. It has recently been suggested to include aviation emission

10 into trading schemes. However, Forster et al. (2006) conclude that it is yet too early as the issue is not sufficiently investigated.

In this paper we study impacts of alternative routings, namely increasing or decreasing cruise altitudes of aircraft as well as making more extensive use of polar routing. In the EU FP5 research project TRADEOFF, several groups worked on estimates of the 15 radiative forcings from aviation. Some main results from the project were summarized in Sausen et al. (2005). For this paper four Chemistry Transport Models (CTMs) and Climate-Chemistry Models (CCMs) have been used in combination with three radiative transfer models to estimate the direct forcing due to ozone. Chemical impacts on $\mathrm{OH}$ have also been estimated by the CTM/CCMs. The $\mathrm{OH}$ perturbations have been used to derive changes in methane, and a simple analytical relation (IPCC, 2001) has been used to derive impacts on the radiative forcing due to methane change. Alternative routings may also imply changes in the fuel use and thus emissions of $\mathrm{CO}_{2}$. This has also been taken into account in this work in terms of changes in radiative forcings, again using an analytical relation (IPCC, 2001).

\section{Models}

In this work we have estimated aircraft-induced $\mathrm{OH}$ and $\mathrm{O}_{3}$ changes. The perturbations to the concentrations of these species resulting from aviation $\mathrm{NO}_{\mathrm{x}}$ emissions were

TRADEOFFs in climate effects

through aircraft routing

F. Stordal et al.

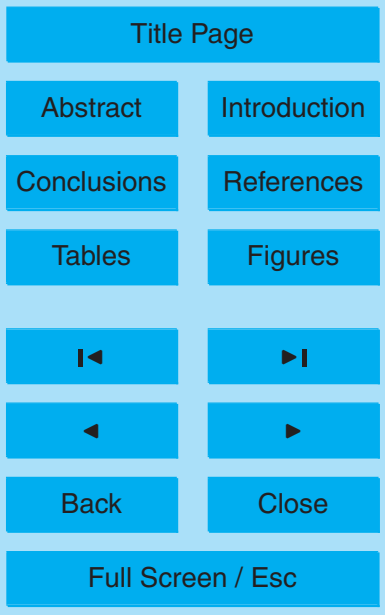

Printer-friendly Version

Interactive Discussion 
calculated with four Chemical Transport Models (CTMs) and Climate-Chemistry Models (CCMs). The four models have been evaluated by Brunner et al. $(2003,2005)$. The main model characteristics are described in the following. The three first models have included also calculations of RF due to ozone, whereas the fourth model estimated changes in ozone and $\mathrm{OH}$ concentrations only.

\subsection{Oslo CTM2}

The Oslo CTM2 model is a 3-D chemical transport model driven by ECMWF meteorological data and extending from the ground to $10 \mathrm{hPa}$ in 40 vertical layers. The horizontal resolution can be varied, but for this study it was set to T21 $\left(\sim 5.6^{\circ} \times 5.6^{\circ}\right)$.

10 Advection applies the Second Order Moment scheme of Prather (1986), while convection is based on the Tiedtke (1989) mass flux scheme. Transport in the boundary layer is treated according to the Holtslag K-profile method (Holtslag et al., 1990), and the calculation of dry deposition follows Wesely (1989). Surface emissions are taken from the EDGAR data base (Olivier et al., 1999) for anthropogenic, and from Mueller 15 (1992) for natural emissions. Lightning emissions of $\mathrm{NO}_{\mathrm{x}}$ are parameterized based on Price et al. $(1997 \mathrm{a}, \mathrm{b})$ and scaled to $5 \mathrm{Tg}(\mathrm{N}) /$ year. The model calculates the distribution of 98 chemical compounds relevant for tropospheric and stratospheric chemistry applying two comprehensive chemistry modules, one for the troposphere (Berntsen and Isaksen, 1997a, 1999) and one for the stratosphere (Rummukainen et al., 1999), 20 which both use the QSSA numerical solver (Hesstvedt et al., 1978). Photo-dissociation rates are calculated by the Fast-J module (Wild et al., 2000). The model was evaluated recently by Isaksen et al. (2005) and Brunner et al. $(2003,2005)$. A procedure to include small scale effects on formation of ozone from $\mathrm{NO}_{x}$ emissions has been included (Kraabøl et al., 2002). In general, this reduced the $\mathrm{NO}_{\mathrm{x}}$ increase and thus the ozone 25 formation due to aircraft, as will be discussed later.

The radiative transfer calculations are calculated by a separate model using different schemes for longwave and shortwave radiation (Berntsen et al., 1997b; Myhre et al., 2000), which have been used in several studies of radiative forcing due to ozone

TRADEOFFs in climate effects through aircraft routing

F. Stordal et al.

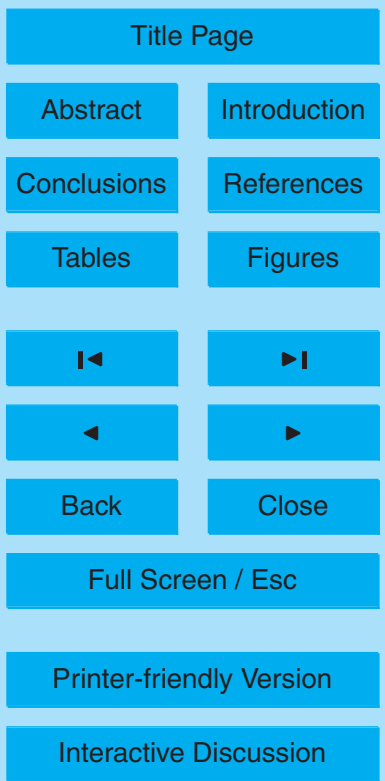


changes (e.g. Gauss et al., 2006). The meteorological data used in the radiative transfer calculations are consistent with the Oslo CTM2 simulations. However, the calculations are performed with monthly mean data.

\subsection{LMDz/INCA GCM}

5 LMDz (version 3.3) is a GCM developed initially for climate studies (Sadourny and Laval, 1984). The model has been adapted in order to simulate the transport of trace species and is coupled on-line to the chemistry-aerosols model INCA (INteraction with Chemistry and Aerosols). The present version of the model has 19 hybrid levels from the surface to $3 \mathrm{hPa}$ and a horizontal resolution of 2.5 degrees in latitude and 3.75 degrees in longitude. The large-scale advection of tracers is performed using a finite volume transport scheme (Van Leer, 1997) as described in Hourdin and Armengaud (1999). Convective transport is simulated using a massflux scheme (Tiedtke, 1989). The planetary boundary layer scheme is based on a second-order closure approximation. The current version of the model uses a $\mathrm{CH}_{4}-\mathrm{NO}_{\mathrm{x}}-\mathrm{CO}-\mathrm{O}_{3}$ chemical scheme representative of the background chemistry of the atmosphere and including 19 photochemical reactions and 66 chemical reactions. INCA calculates on-line the time evolution of 33 chemical species and tracers with a time step of $30 \mathrm{~min}$. In the present version of the model, the feedback of the chemistry on the radiation is not taken into account. A zonally and monthly ozone climatology is prescribed above the tropopause based on Li and Shine (1995). An interactive lightning $\mathrm{NO}_{\mathrm{x}}$ emission scheme is used in the model (Jourdain and Hauglustaine, 2001). While the LMDz GCM wind fields can be relaxed towards ECMWF reanalysis, this model feature is not activated in the version of LMDz used in this study and the GCM winds fields, temperature, humidity and cloudiness are used to drive the transport and chemistry of the chemical species. A detailed description and evaluation of the model is provided by Hauglustaine et al. (2004).

The ozone radiative forcings at the tropopause are calculated with an off-line version of the LMDz GCM radiative transfer model. The model is based on the European Centre for Medium-Range Weather Forecasts (ECMWF): a refined version of the scheme

TRADEOFFs in climate effects

through aircraft routing

F. Stordal et al.

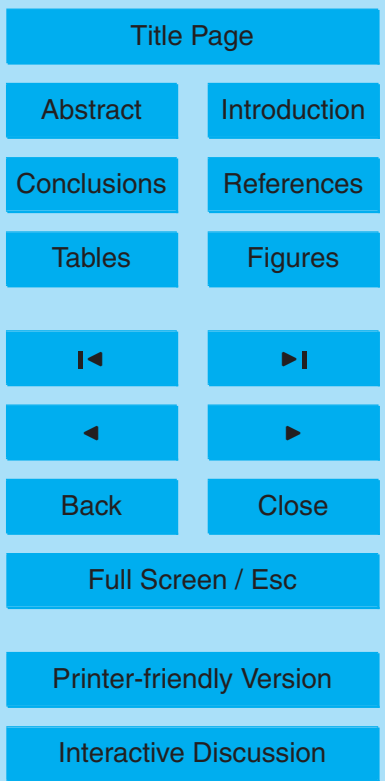


developed by Fouquart and Bonnel (1980) in the solar part of the spectrum and by Morcrette (1991) in the thermal infrared. The forcings are calculated on a monthly mean basis using the temperature, water vapour, cloud distributions and optical properties, surface albedo, and ozone fields stored from a previous GCM simulation and

5 read from pre-established history files. The fixed-dynamical heating concept is applied to the calculations.

\subsection{ULAQ CTM}

ULAQ model from the University of L'Aquila is a low-resolution three-dimensional aerosol-chemistry-transport model that uses a $10 \times 22.5$ degree resolution in latitude10 longitude and 26 log-pressure levels, from the ground to about $0.04 \mathrm{hPa}$, with an approximate resolution of $2.84 \mathrm{~km}$. Dynamical fields are taken from the output of a spectral general circulation climate model (Pitari et al., 2002). The chemical module contains the most important photolytic, gas phase and heterogeneous reactions relevant for stratospheric chemistry, including $\mathrm{O}_{\mathrm{x}}, \mathrm{HO}_{\mathrm{x}}, \mathrm{NO}_{\mathrm{y}}, \mathrm{ClO}_{\mathrm{x}}, \mathrm{BrO}_{\mathrm{x}}, \mathrm{CHO}_{\mathrm{x}}$ and $\mathrm{SO}_{\mathrm{x}}$ fam15 ilies. Sulphur precursors in the model are $\mathrm{SO}_{2}$, OCS, DMS, $\mathrm{H}_{2} \mathrm{~S}$, and $\mathrm{CS}_{2}$, with $\mathrm{SO}_{2}$ being the most important species for the sulphur budget into the lower stratosphere, and OCS for the middle stratosphere. $\mathrm{SO}_{2}$ comes from both natural sources (volcanoes, oceans, biomass burning) and anthropogenic activities (fossil fuel burning, in situ emissions from aircraft) and is efficiently transported from the boundary layer up to 20 the tropical tropopause layer via deep convection (Pitari et al., 2002). The model also includes the major components of tropospheric and stratospheric aerosols (sulphate, carbonaceous, dust, sea salt).

The ULAQ-GCM has been used to calculate the different components of the radiative forcing. $\mathrm{O}_{3}, \mathrm{H}_{2} \mathrm{O}, \mathrm{BC}$ and sulphate fields are taken from the ULAQ-CTM simulations. 25 The infrared contribution to the cooling rate by the $0_{3} 9.6-\mu \mathrm{m}$ band has been evaluated following the assumption of "cooling to space" (Andrews et al., 1987). $\mathrm{O}_{3}$ absorption in the UV and visible wavelengths is calculated from tabulated solar fluxes and cross sections.

TRADEOFFs in climate effects through aircraft routing

F. Stordal et al.

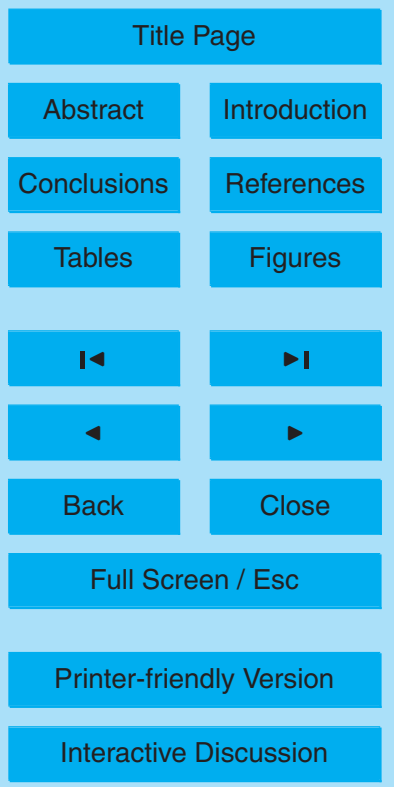




\subsection{TOMCAT CTM}

is a global three-dimensional chemistry transport model (Law et al., 1998, 2000) and in its configuration used for this study the model has recently undergone a rigorous validation with airborne in-situ observations (Brunner et al., 2003, 2005). The model domain 5 extends from the surface to $10 \mathrm{hPa}$ with 31 hybrid pressure levels and the horizontal resolution is 5.6 by 5.6 degrees. Using meteorological forcing from the ECMWF the model uses the Prather (1986) advection scheme with conservation of second-order moments and a dynamical time step of $30 \mathrm{~min}$. Moist convective transport of tracers is parameterised by the Tiedtke (1989) mass flux scheme. Lightning $\mathrm{NO}_{\mathrm{x}}$ emissions are coupled to the convection scheme (Price and Rind, 1992; Stockwell et al., 1999). The model also includes the Holtslag and Boville (1993) non-local vertical diffusion scheme, based on the NCAR Community Climate Model Version 2 (CCM2), which calculates explicitly the height of the planetary boundary layer (Wang et al., 1999) TOMCAT uses the ASAD chemistry package (Carver et al., 1997) which describes gas phase $\mathrm{CH}_{4}$ $\mathrm{CO}-\mathrm{NMHC}-\mathrm{NO}_{\mathrm{x}}$ chemistry, using a chemical time step of 15 minutes. In 28 photolytic, 89 bimolecular and 15 termolecular reactions the TOMCAT model considers 47 chemical species, of which 27 are advected. Rate coefficients are taken from Atkinson et al. (1997) and DeMore et al. (1997), photolysis rates are calculated off-line in the Cambridge 2-D Model (Law and Pyle, 1993). The simplified treatment of NMHCs considers the degradation of ethane and propane. TOMCAT also takes account of loss through dry deposition at the surface, moreover a wet scavenging scheme based on the occurrence of convective and large-scale rainfall (Giannakopoulos et al., 1999) is included.

\section{ACPD}

6, 10733-10771, 2006

TRADEOFFs in climate effects

through aircraft routing

F. Stordal et al.

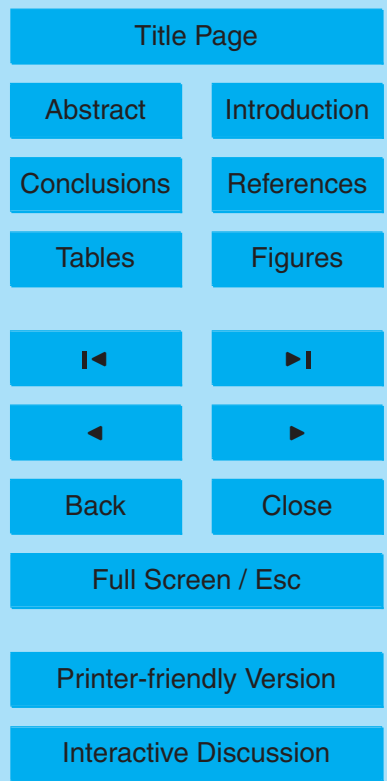




\section{Assumptions}

\subsection{Base case fuel burn and $\mathrm{NO}_{\mathrm{x}}$ emissions}

In the model simulation performed for this work we focus on effects of aircraft in year 2000 and various perturbation scenarios for the same year. In the analysis of the 5 climate impact we also consider the long term effects on radiative forcing (cf. Sect. 3.3). The cases and model experiments are summarized in Table 1. Aircraft emissions are based on 1991/92 aircraft movements, corrected by ICAO statistics through to 2000 and converted into emissions, fuel burn and distance travelled (Stordal et al., 2005; Sausen et al., 2005). In the cases used in our study military aircraft are neglected

10 (Gauss et al., 2006), reducing fuel burn by approximately $10 \%$. This must be kept in mind when changes in chemistry and radiative forcing are discussed. However, in the perturbation cases where we investigate impacts of alternative routings it is fair to assume that the civil traffic could be more easily rerouted than the military one. The global $\mathrm{NO}_{\mathrm{x}}$ emission amounts to $0.594 \mathrm{Tg}(\mathrm{N})$ and the total fuel burn is $152 \mathrm{Tg}$ per year. We have not scaled our radiative forcings by a factor of 1.15 as has been done by other investigators (e.g. IPCC, 1999) in order to account for extra fuel burn due to non-perfect routing, sub-optimal cruise altitude, holding cycles, etc.

\subsection{Alternative routing cases}

A main emphasis in this work is on impacts of alternative routing. Polar routes are used increasingly on long distance intercontinental flights. As the chemistry is quite different in polar regions compared to middle latitudes we investigate the impact of an additional fraction of polar routes. When implementing additional polar routes we have kept the total global emissions fixed in order to isolate the impact of their redistribution. Thus we assume that polar routes are added at the expense of non-polar routes so that the amount of fuel burnt is not affected (Table 1). Further, flying at different altitudes will potentially alter the climate impact of aircraft. Such effects clearly need to be in-
TRADEOFFs in climate effects

through aircraft routing

F. Stordal et al.

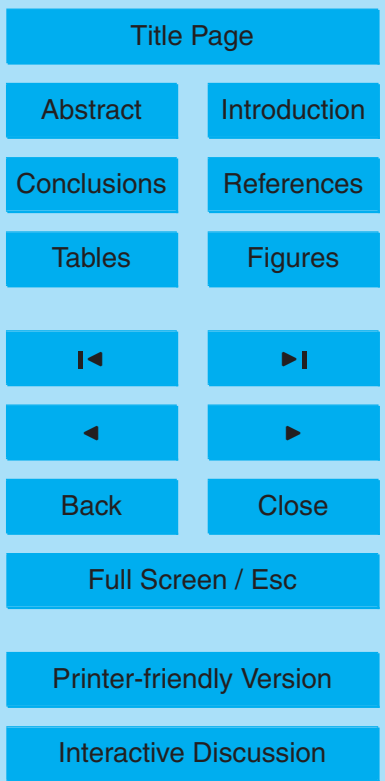


vestigated in order to understand whether and how alternative routing may be used to reduce the climate impact of air traffic. Also the aviation industry will consider options to reduce the fuel consumption. Operating at higher flight levels is an option working in this direction.

$5 \quad$ We have chosen to focus on three different alternative routing scenarios defined in the TRADEOFF project, namely one scenario assuming additional polar routes and two scenarios assuming aircraft cruising at higher $(+2000 \mathrm{ft})$ and lower $(-6000 \mathrm{ft})$ altitudes. Notice that in the case of altered cruise altitudes fuel burn as well as $\mathrm{NO}_{\mathrm{x}}$ emission indices will be modified (see details in Table 1). The calculated impacts on the chemical 10 changes due to alternative routings are partly due to changes in emission totals, which are listed in Table 1, but more due to the fact that emissions take place at different locations compared to the base case (Gauss et al., 2006).

\subsection{Forcing estimates}

The radiative forcing of the $\mathrm{CH}_{4}$ change is estimated from a change in $\mathrm{CH}_{4}$ lifetime 15 resulting from the $\mathrm{OH}$ change simulated with the CTMs. In estimating the methane forcing we have used the model derived reductions in the methane lifetime, which has been multiplied with a factor 1.4 to take into account feedback mechanisms (Berntsen et al., 2004, 2005; Derwent et al., 1999; Isaksen et al., 1999; Prather et al., 2001). The inferred change in global tropospheric methane has been used to estimate the 20 RF adopting the analytical relation between methane and its RF given in IPCC (2001, Chapter 6). The CTM simulations and further calculations with radiative transfer models give the RF for the short-term perturbation of ozone. However, as described by Prather (1996) and Wild and Prather (2000), the long term (primary mode) change in methane (which is not captured directly in the CTMs due to the short integration time)

25 will also cause perturbation in ozone with a timescale corresponding to the perturbation lifetime of methane. Here we follow the procedure described in Appendix 2 of Berntsen et al. (2005) to estimate the radiative forcing of this effect.

The RF from aviation $\mathrm{CO}_{2}$ has been derived based on EDGAR emission data (Olivier

TRADEOFFs in climate effects

through aircraft routing

F. Stordal et al.

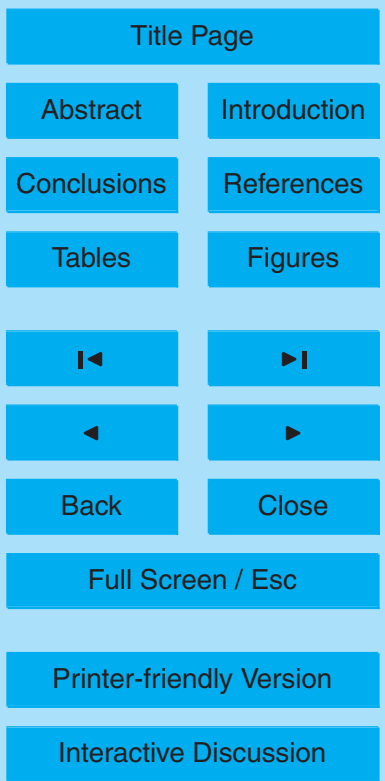


and Berdowski, 2001) assuming a decay function for $\mathrm{CO}_{2}$ taken from IPCC (1995); $\mathrm{CO}_{2}(\mathrm{t})=\mathrm{CO}_{2}(0) *(0.30036 \exp (-\mathrm{t} / 6.993)+0.34278 \exp (-\mathrm{t} / 71.109)+0.35686 \mathrm{exp}(-$ $\mathrm{t} / 815.727)$. We have applied the analytical relation between mixing ratio change and RF in IPCC (2001, Chapter $\left.6,15.48 \mathrm{mWm}^{-2} / \mathrm{ppm}\right)$. In the base case for year 2000 5 used in this work this forcing is $21.7 \mathrm{mWm}^{-2}$. This is lower than the $25 \mathrm{mWm}^{-2}$ given in Sausen et al. (2005) as military traffic and the upscaling to account for non-perfect routing have been neglected here. Whereas the fuel burn grew somewhat faster from 1992 to 2000 than assumed by IPCC (1999) a slightly smaller RF per unit $\mathrm{CO}_{2}$ increase is assumed now (IPCC, 2001 vs. IPCC, 1999, Myhre et al., 1998).

10 Assessing the effects of alternative routing can be done in several ways. First we take a simple approach by looking backward and assuming that all flights in the past have been according to the alternative routings. Thus we are estimating the accumulated effect of the various alternatives in the past. This is done by scaling the present $\mathrm{CO}_{2}$ concentrations by the changes in fuel consumption and present $\mathrm{CH}_{4}$ concentrations by 15 the change in the methane lifetime.

Another approach is more useful in order to assess future impacts of alternative routing, namely to look forward and estimate the changes in time integrated radiative forcing over a time span when alternative routing may be assumed to be in effect. We have taken also this approach in this work by investigating future changes on time horizons of 20 and 100 years (used as time horizons in estimates of GWP by IPCC). We are assuming constant emissions and flight patterns over these time horizons. $\mathrm{NO}_{\mathrm{x}}$ and ozone have relatively short lifetimes, and we assume that the forcing for ozone that we have calculated from the steady state experiments is obtained instantaneously and is sustained over the 20 and 100 year time horizons. For $\mathrm{CO}_{2}$ and $\mathrm{CH}_{4}$ we take into 25 account the accumulated effect over the 20 and 100 years time periods due to the change in emissions in the first case and the change in the loss in the latter case. We have first estimated the time evolution in the global average mixing ratios (in ppm) of $\mathrm{CO}_{2}$ and $\mathrm{CH}_{4}$ due to aircraft emissions in the base case and the alternative routing cases. In these calculations we have assumed the same decay function for pulses

TRADEOFFs in climate effects

through aircraft routing

F. Stordal et al.

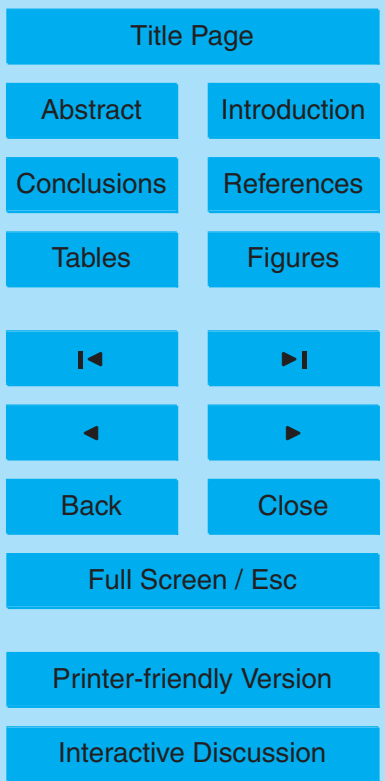


of $\mathrm{CO}_{2}$ as given above. Second, we have integrated the changes in mixing ratios (deviation from the case without aircraft in the base case, deviations from the base case in the alternative routing cases; in ppm yr). Finally, we have multiplied with the specific radiative forcing (in $\mathrm{mWm} / \mathrm{ppm}$; as described above for $\mathrm{CH}_{4}$ and $\mathrm{CO}_{2}$ ), resulting in 5 an integrated forcing over the 20 and 100 year time periods (in $\mathrm{Wm}^{-2} \mathrm{yr}$ ).

\section{Results}

\subsection{Base case 2000}

Results for the base case in year 2000 are discussed in more detail elsewhere (Sausen et al., 2005; Gauss et al., 2006). We include only a brief presentation which is needed 10 to put the results of the perturbation studies in perspective. The ozone changes due to $\mathrm{NO}_{\mathrm{x}}$ emissions are largest at mid and high latitudes in the Northern Hemisphere $(\mathrm{NH})$ (Fig. 1a). Maximum perturbations are modelled during late spring and early summer (see e.g. Gauss et al., 2006). Near the maximum aircraft traffic at mid latitudes in $\mathrm{NH}$ Oslo CTM2 estimates somewhat lower impact of aircraft than the LMDz/INCA and 15 TOMCAT models, most likely due to the reduced effect from small scale effects, which reduces the impact on ozone by up to $20 \%$. The latitudinal gradient in the ozone increase from mid to high latitudes in $\mathrm{NH}$ varies quite substantially between the models. The flights are predominantly in the stratosphere at high latitudes. Thus differences in stratosphere-troposphere exchange and meridional transport between the models yield 20 large differences in impacts of $\mathrm{NO}_{\mathrm{x}}$ emissions. The total amount of ozone added is in the range 0.31 to $0.45 \mathrm{DU}$ globally (Table 2). Further, the $\mathrm{NO}_{\mathrm{x}}$ emissions lead globally to increased $\mathrm{OH}$ concentrations and a reduced lifetime of methane. In the three models the lifetime change is in the range $-0.7 \%$ to $-1.6 \%$ (Table 3 ).

The RF from short term ozone perturbations is also largest at mid and high latitudes 25 in the $\mathrm{NH}$ (Fig. 2). The time of the maximum is shifted somewhat towards the summer (not shown here, see e.g. Gauss et al., 2006), due to the higher elevation of the sun

TRADEOFFs in climate effects through aircraft routing

F. Stordal et al.

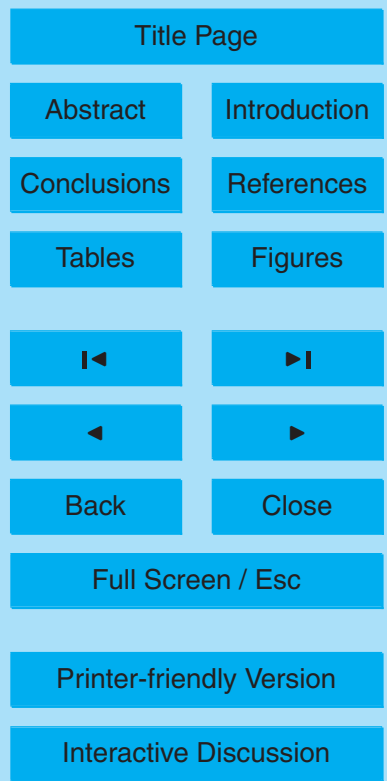


effecting the shortwave component of the forcing. The global forcing is in the range 11 to $16 \mathrm{mWm}^{-2}$ (mean $14 \mathrm{mWm}^{-2}$ ) in the three estimates made here (Table 4). Sausen et al. (2005) reported forcings due to ozone in the range 12 to $28 \mathrm{mWm}^{-2}$ resulting from TRADEOFF, with an average value of $19 \mathrm{mWm}^{-2}$ (scaled to $22 \mathrm{mWm}^{-2}$ ). As 5 there are fewer models contributing to this work, the interval is somewhat narrower than in Sausen et al. (2005), and the mean value is somewhat lower as a lower traffic scenario (without military aircraft) has been assumed. Even the Sausen et al. (2005) $\mathrm{RF}$ is somewhat smaller than the IPCC-based estimate for 2000; however, in the light of the large confidence interval this difference is not significant. The long-term (primary 10 mode, cf. Sect. 3.3) forcing due to ozone was not estimated by Sausen et al. (2005). For the base case, we estimate this RF to be between -6 and $-3 \mathrm{mWm}^{-2}$ (when the system has reached a new steady state).

The corresponding RF from aircraft-induced $\mathrm{CH}_{4}$ loss is in the range -6 to $14 \mathrm{mWm}^{-2}$ (mean $-10 \mathrm{mWm}^{-2}$ ) based on the four estimates here (Table 5). In es15 timating the methane forcing we have used the reductions in the methane lifetime from Table 3, which has been up-scaled to take into account the feedback mechanism through $\mathrm{OH}$ changes (Sect. 3.3). Thereafter the inferred change in global tropospheric methane has been used to estimate the RF adopting an analytical expression. The methane RF given in Sausen et al. (2005) was similar, namely $-9 \mathrm{~mW} / \mathrm{m}^{2}$ (scaled to

$20-10 \mathrm{~mW} / \mathrm{m}^{2}$ ). Our results are lower than the IPCC-based estimate, but still within the confidence interval of IPCC (1999).

As mentioned in Sect. 3 the forcing due to $\mathrm{CO}_{2}$ in the base case is $21.7 \mathrm{mWm}^{-2}$ (Table 6). This is somewhat larger in magnitude than the ozone and methane forcings, working in the same direction (heating) as the ozone forcing but opposite to the 25 methane forcing (cooling).

\subsection{Additional polar routes}

Two models have been run for this case. In both models there is less ozone production due to aircraft at middle latitudes in the $\mathrm{NH}$, as some flights are moved from these to 10745

TRADEOFFs in climate effects through aircraft routing

F. Stordal et al.

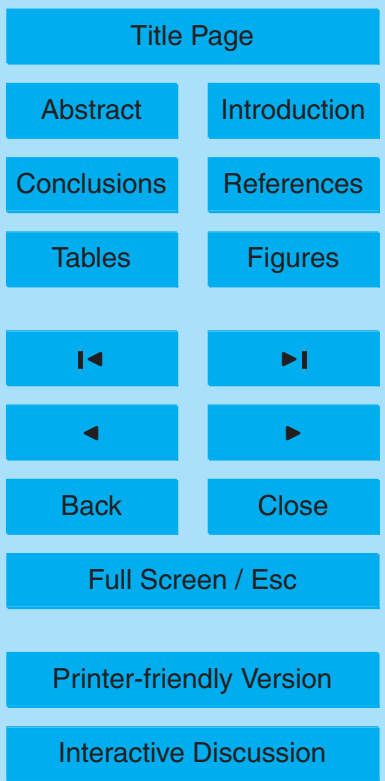


higher latitudes. However, only in one of the models (Oslo CTM2) there is a partly compensating increased ozone production at the high latitudes (Fig. 1b) in the yearly average. The other model (ULAQ) has a coarser spatial resolution that most probably explains the model difference. Thus there is a wide range in the change in global total 5 ozone; -0.0089 to $-0.0467 \mathrm{DU}$ (Table 2). In Fig. 3 we see that in the polar region both models estimate a strong seasonal variation in ozone changes. Whereas the Oslo CTM2 model has only weak changes during the winter, the ULAQ model estimates ozone loss at that time of the year. On the other hand the expected ozone increase during the summer is much stronger in the Oslo CTM2 than in the ULAQ model.

10 The impact on radiative forcing due to ozone is quite similar, with reduced $R F$ at middle latitudes in the $\mathrm{NH}$ in both models, and a partly compensating increase at high latitudes in one of the models (Fig. 2). The range of changes in net (short-term and primary mode) RF on a global scale is therefore also large, namely +0.06 to $1.15 \mathrm{mWm}^{-2}$ (Tables 4 and 7 ). The seasonal variation at high latitudes depicts the 15 same pattern as the changes in ozone (Fig. 3). The RF due to changes in methane is more similar in the two models (Table 5). It is significant in comparison with the forcing due to ozone and it works in the different direction (warming by methane vs cooling in the ozone case), namely in the range 0.73 to $0.99 \mathrm{mWm}^{-2}$. As we have assumed no change in fuel burn (Sect. 3.2) in this experiment $\mathrm{CO}_{2}$ emission are the same as in the base case and there is no change in the RF due to $\mathrm{CO}_{2}$ (Table 6).

\subsection{Lower cruise altitudes}

We investigate next the impact of lower cruise altitudes, and we use the TRADEOFF scenario where the flight levels are reduced by $6000 \mathrm{ft}$. Three models (Oslo CTM2, LMDz/INCA and TOMCAT) estimate a decrease in ozone (Table 2), especially at mid25 dle and high $\mathrm{NH}$ latitudes (Fig. 1). In these three models the ozone loss resulting from aircraft NOx emissions is reduced by -4 to $-13 \%$ as a result of $6000 \mathrm{ft}$ (approximately $1.8 \mathrm{~km}$ ) reduced cruise altitudes. This is a somewhat weaker effect than the $10 \%$ reduction estimated by Grewe et al. (2002c) for a $1 \mathrm{~km}$ lower cruise altitude. In

TRADEOFFs in climate effects

through aircraft routing

F. Stordal et al.

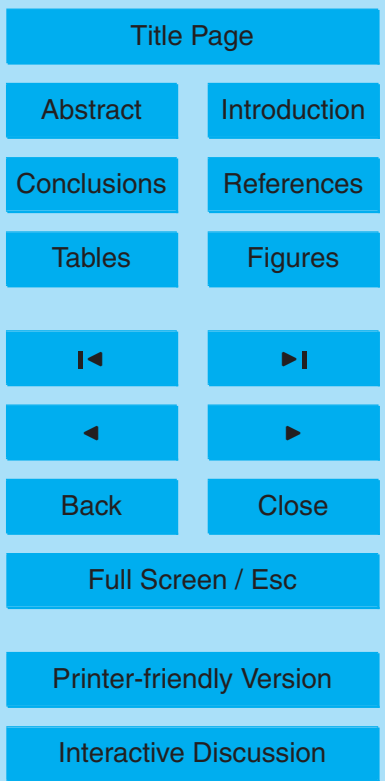


LMDz/INCA the ozone reductions are largest at high latitudes, probably as a result of a quite efficient meridional transport in this model. The three other models have largest changes at middle latitudes, near the maximum of the impact of aircraft emissions of $\mathrm{NO}_{\mathrm{x}}$ on ozone. Like in LMDz/INCA the ozone change is negative in Oslo CTM2 and 5 TOMCAT as expected, due to a shorter lifetime for $\mathrm{NO}_{x}$ as well as ozone. However, it is positive in ULAQ, which is more difficult to explain. Figure 4 a shows that in Oslo CTM2 there is an increase in ozone at high latitudes during the winter and a decrease in the summer. In LMDz/INCA there is an ozone decrease throughout the year with a maximum decrease during the summer which is much stronger than in Oslo CTM2. The 10 ULAQ model estimates increases in ozone, particularly strong at middle $\mathrm{NH}$ latitudes (Fig. 1), prevailing throughout the year (Fig. 4). At high latitudes this model estimates negative ozone changes only for the spring and early summer seasons. As in the base case the differences between the models are largest at high latitudes, as discussed in Sect. 4.1. The radiative forcing due to ozone follows patterns which parallel those of 15 the changes in ozone in each of the three models (Figs. 2 and 4). The range of global and seasonal averaged forcings due to the net ozone changes in this case is -1.88 to $+0.14 \mathrm{mWm}^{-2}$ (Tables 4 and 7 ).

Although the ozone changes are both positive and negative in the three models, the changes in $\mathrm{OH}$ and thus methane are in the same direction in all models. However, the range between the models is large, namely -0.15 to $-3.17 \mathrm{mWm}^{-2}$ (Table 5). In this scenario the magnitude of the forcing due to $\mathrm{CO}_{2}$ related to increased fuel burn is $1.27 \mathrm{mWm}^{-2}$ (Table 6).

\subsection{Higher cruise altitudes}

Next we investigate the impact of higher cruise altitudes. In this case the levels are 25 increased by $2000 \mathrm{ft}$. Consequently, one would expect a somewhat weaker impact than in the previous case where the magnitude of altitude change was three times larger $(6000 \mathrm{ft})$. The ozone perturbations in the three models that gave ozone decrease in the previous case are now positive. The signal is somewhat lower, but stronger than $1 / 3$ of

TRADEOFFs in climate effects

through aircraft routing

F. Stordal et al.

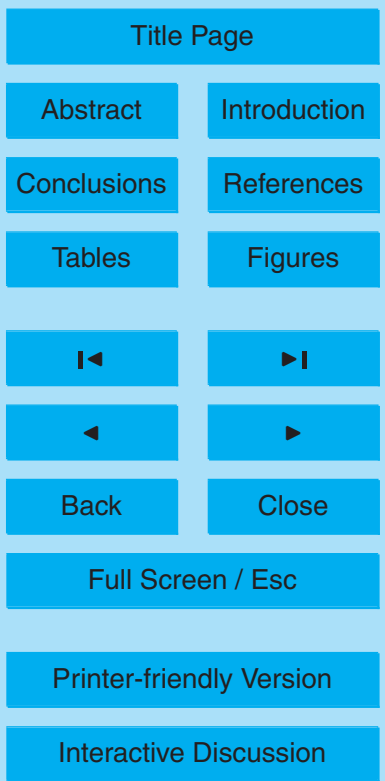


the signal in the reduced cruise altitude case (Table 2). The latitudinal patterns in the changes are similar (Fig. 1), except for the model that predicted ozone decrease in the previous case, as this model also gives positive ozone perturbation in this case. The ozone RF results are quite parallel to the results for ozone itself (Fig. 2). The range of 5 net RF due to ozone is +0.51 to $+0.87 \mathrm{mWm}^{-2}$ (Tables 4 and 7 ).

Based on the results for changes in RF from methane it seems like currently aircraft fly at a level with near a maximum impact on methane RF, as two models predict reductions in the $\mathrm{RF}$ for lower as well as higher cruise altitudes, and the remaining two models estimate only very weak positive changes in the RF in the higher cruise to altitude case. The range of the methane forcing is -0.48 to $+0.09 \mathrm{mWm}^{-2}$ (Table 5). The magnitude of the forcing due to $\mathrm{CO}_{2}$ in this scenario has switched sign compared to the reduced altitude case, but the absolute magnitude is reduced by much more than a factor 3 , as the forcing is $-0.11 \mathrm{mWm}^{-2}$ (Table 6).

\section{Discussion and summary}

15 The TRADEOFF project has provided an opportunity to study climate impacts of alternative aircraft routings. In this work we focus only on radiative forcing due to greenhouse gases, namely ozone, methane and $\mathrm{CO}_{2}$. As a reference we have estimated the forcing due the three greenhouse gases due to aircraft traffic in year 2000. The data that we have used exclude military aircraft. The forcings from the three gases are well within the confidence intervals of IPCC (1999) and consistent with the TRADEOFF summary paper of Sausen et al. (2005). The forcings due to ozone (net change), methane and $\mathrm{CO}_{2}$ are 8.2 to $14,-6.3$ to -14 , and $22 \mathrm{mWm}^{-2}$, respectively. Adding the numbers model by model (for Oslo-CTM2, LMDz/INCA and ULAQ), the range of the total forcing from all the three gases is 21 to $29 \mathrm{mWm}^{-2}$.

As discussed in Sect. 3.3 we are taking two different approaches when assessing the impact of the alternative routings investigated here; a backward looking and a forward looking approach. Taking first the backward looking approach, adding the changes in

TRADEOFFs in climate effects

through aircraft routing

F. Stordal et al.

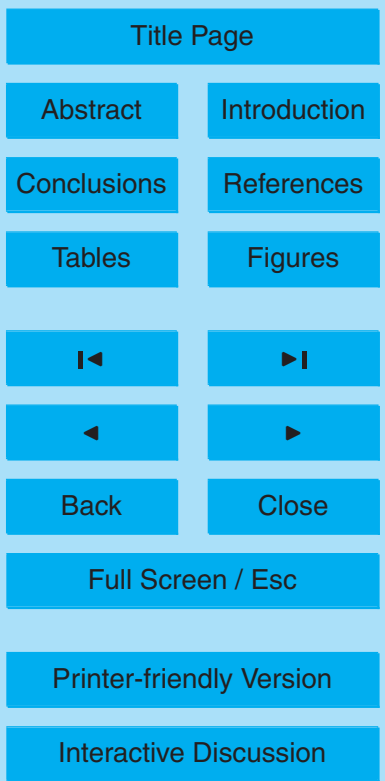


the forcing from ozone, $\mathrm{CO}_{2}$ and $\mathrm{CH}_{4}$, the ranges of the models used in this work are -0.8 to -1.8 and 0.3 to $0.6 \mathrm{mWm}^{-2}$ in the lower $(-6000 \mathrm{ft})$ and higher $(+2000 \mathrm{ft})$ cruise levels, respectively. These numbers are relatively moderate compared to the forcing in the base case. In relative terms, flying $6000 \mathrm{ft}$ lower reduces the forcing by $5-10 \%$, whereas flying higher, while saving fuel and presumably flying time, increases the forcing by about $2-3 \%$. However, the uncertainty is considerable in these estimates. One important source of uncertainty, in particular at high latitudes, is differences in transport (most importantly stratosphere-troposphere exchange and meridional circulation) between models, especially since aircraft emissions take place partly in the troposphere 10 (mid latitudes) and in the stratosphere (high latitudes), yielding significant differences between the models. The differences are even larger for the additional polar routes scenario. Unfortunately, only two models have run this case, and they give different signs in the change in the radiative forcing. The range of the forcing in this case is -0.4 to $+1.1 \mathrm{mWm}^{-2}$, which amounts to roughly a $2-4 \%$ impact, positive or negative, 15 compared to the base case.

Taking next the forward looking approach we have estimated the integrated forcing $\left(\mathrm{mWm}^{-2} \mathrm{yr}\right)$ over 20 and 100 years time horizons, as explained above. The results are summarized in Table 8. Basis for the results are averages in methane life times between four models (Table 3 ) and ozone forcings from three models (short term plus primary mode, Tables 4 and 7 ). We have made projections for the base case and the lower and higher cruise altitude cases, but not for the additional polar routing cases where only two models have provided data and the discrepancy between the models is large. In Table 8 the results are presented in terms of integrated radiative forcing over 20 and 100 years time horizon (in $\mathrm{mWm}^{-2} \mathrm{yr}$ ) and also relative to the contributions from

$\mathrm{CO}_{2}$ (for each of the two time horizons separately, in \%) to ease the assessment of the relative contributions of each of the contributions.

In the forward looking approach the relative contributions are somewhat different from the backward looking approach. The differences are moderate adopting 100 year time horizon, whereas under the 20 year horizon $\mathrm{CO}_{2}$ naturally becomes less impor-

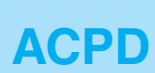

6, 10733-10771, 2006

TRADEOFFs in climate effects

through aircraft routing

F. Stordal et al.

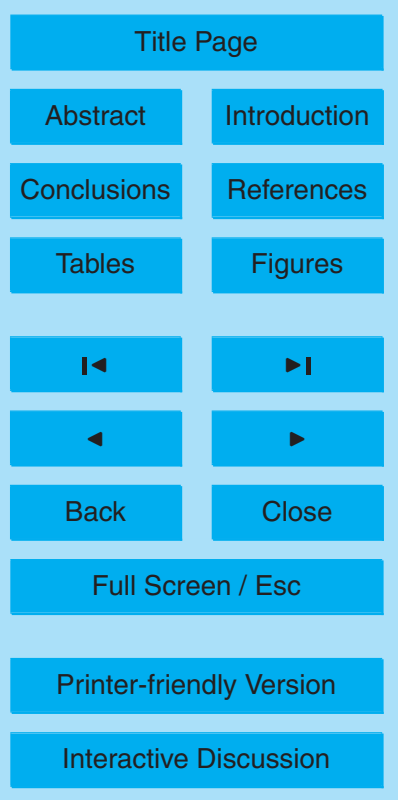


tant relatively. The situation regarding the relative contribution for $\mathrm{CO}_{2}$ is similar in the alternative routing cases. The relative importance of $\mathrm{O}_{3} \mathrm{vs} \mathrm{CH}_{4}$ follows a similar pattern, with ozone being more important than methane (ozone heating, methane cooling) in the base case, most pronounced under the forward looking 20 year time horizon.

In the alternative routing cases the total forcing is highly dependent on the method that is used for evaluation, as the contributions from $\mathrm{O}_{3}, \mathrm{CH}_{4}$ and $\mathrm{CO}_{2}$ vary in different ways and are comparable in magnitude, so that the net balance differs widely between the various cases. In the higher cruise altitude case the net forcing is positive in all analyses, but it varies from 3.5 to $1.3 \%$ increase in forcing (warming) compared to 10 the base case under the forward looking 20 and 100 year time horizons, respectively. The corresponding increase under the backward looking approach is $1.8 \%$ from the base case. In the lower cruise altitude case the net forcing is negative (cooling) in all analyses, varying from -5.2 to $-0.4 \%$ reduction compared to the base case under the forward looking 20 and 100 year time horizons, respectively. The corresponding change under the backward looking approach is $-5.9 \%$ from the base case. As an example of how sensitive the balance between the individual effects is we can mention that if we neglect the primary mode contribution to the ozone RF, in the lower cruise altitude case the accumulated forcing taking the forward looking approach shifts from cooling under the 20 year to heating under the 100 year horizon. Thus, not only are the changes in the concentrations of ozone and methane uncertain, as demonstrated from the significant differences between the models, but also the forcing agents impact climate differently on various time scales. Thus it is important also to take time scales into account when alternative routings are to be assessed. Thus we agree with Forster et al. (2006) that we are not yet at a point where we can include non- $\mathrm{CO}_{2}$ effects of aviation in emission trading schemes. Nevertheless, the rerouting cases that have been studied here yield relatively small changes in the radiative forcing due to the radiatively active gases.

It is worth noticing that the change in RF from contrails as a result of rerouting could be at least as large as from the gases. E.g. Fichter et al. (2005) found a reduction of

TRADEOFFs in climate effects

through aircraft routing

F. Stordal et al.

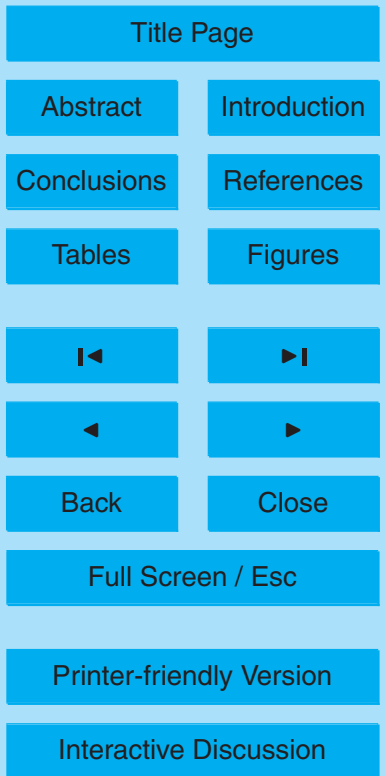


$15 \%$ in RF from contrails for a $6000 \mathrm{ft}$ lower cruise altitude. Using the IPCC (IPCC, 1999) and the TRADEOFF (Sausen et al., 2005) values for RF from contrails this reduction amounts to a change in the RF by -1.5 to $-5 \mathrm{mWm}^{-2}$ in comparison with the -0.8 to $-1.8 \mathrm{mWm}^{-2}$ found in this work for the radiatively active gases.

5 Acknowledgements. This work is based on research which was funded by the Commission of the European Union (TRADEOFF project).

\section{References}

Akerman, J.: Sustainable transport - on track in 2050, Transportation Res. Part D - Transport and Environment, 10, 111-126, 2005.

10 Andrews, D. G., Holton, J. R., and Leovy, C. B.: Middle atmosphere Dynamics. Academic Press, 490 pp., 1987.

Atkinson, R., Baulch, D. L., Cox, R. A., Hampson, R. F., Kerr, J. A.,Rossi, J., and Troe, J.: Evaluated kinetic, photochemical and heterogeneous data for atmospheric chemistry: Supplement V - IUPAC Subcommittee on Gas Kinetic Data. Evaluation for Atmospheric Chemistry, J. Phys. Chem. Ref. Data, 26(3), 521-1011, 1997.

Berntsen, T. and Isaksen, I. S. A.: A global 3-D chemical transport model for the troposphere, 1, Model description and CO and Ozone results, J. Geophys. Res., 102, 21 239-21280, 1997a.

Berntsen, T. K., Isaksen, I. S. A., Myhre, G., et al.: Effects of anthropogenic emissions on tropospheric ozone and its radiative forcing, J. Geophys. Res.-Atmos., 102, 28101-28126, 1997b.

Berntsen, T. K. and Isaksen, I. S. A.: Effects of lightning and convection on changes in upper tropospheric ozone due to aircraft, Tellus, 51B, 766-788, 1999.

Berntsen, T. K., Fuglestvedt, J. S., Joshi, M., Shine, K. P., Stuber, N., Ponater, M., Sausen, R., Hauglustaine, D., and Li, L.: Climate response to regional emissions of ozone precursors; sensitivities and warming potentials, Tellus Ser. B-Chem. Phys. Meteorol., 4, 283-304, 2005.

Berntsen, T. K., Gauss, M., Isaksen, I. S. A., Grewe, V., Sausen, R., Pitari, G., Mancini, E., Meijer, E., and Hauglustaine, D.: Sources of $\mathrm{NO}_{\mathrm{x}}$ at cruise altitudes: Implications for predictions

TRADEOFFs in climate effects

through aircraft routing

F. Stordal et al.

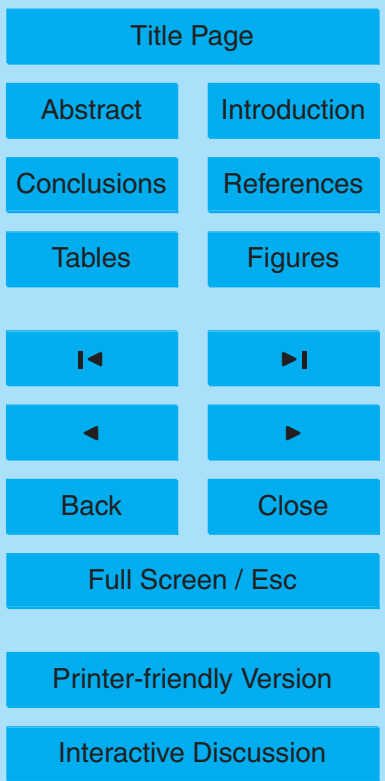


of ozone and methane perturbations due to $\mathrm{NO}_{x}$ from aircraft, in: European Conference on Aviation, Atmosphere and Climate (AAC), edited by: Sausen, R., Fichter, C., and Amanatidis, G., Proceedings of an International Conference Friedrichshafen, Germany, 30 June to 3 July 2003, EUR 21051, 190-196, 2004.

5 Brunner, D., Staehelin, J., Rodgers, H. L., Kohler, M. O., Pyle, J. A., Hauglustaine, D. A., Jourdain, L., Berntsen, T. K., Gauss, M., Isaksen, I. S. A., Meijer, E., van Velthoven, P., Pitari, G., Mancini, E., Grewe, V., and Sausen, R.: An evaluation of the performance of chemistry transport models. Part 2: detailed comparison with two selected campaigns, Atmos. Chem. Phys., 5, 107-129, 2005.

10 Brunner, D., Staehelin, J., Rogers, H. L., Köhler, M. O., Pyle, J. A., Hauglustaine, D. A., Jourdain, L., Berntsen, T. K., Gauss, M., Isaksen, I. S. A., Meijer, E., van Velthoven, P., Pitari, G., Mancini, E., Grewe, V., and Sausen, R.: An evaluation of the performance of chemistry transport models by comparison with research aircraft observations. Part 1: concepts and overall model performance, Atmos. Chem. Phys., 3, 1606-1631, 2003.

Carver, G. D., Brown, P. D., and Wild, O.: The ASAD atmospheric chemistry integration package and chemical reaction database. Comput. Phys. Commun., 105, 197-215, 1997.

DeMore, W. B., Sander, S. P., Howard, C. J., Ravishankara, A. R., et al.: Chemical kinetics and photochemical data for use in stratospheric modelling: Evaluation number 12. JPL Publication, 97-4, 14-153, 1997.

20 Derwent, R., Friedl, R., Karol, I. L., Kirchhoff, V. W. J. H., Ogawa, T., Rossi, M. J., and Wennberg, P.: Impacts of aircraft emissions on atmospheric ozone, in: Aviation and the Global Atmosphere. A Special Report of IPCC Working Groups I and III, edited by: Penner, J. E., Lister, D. H., Griggs, D. J., Dokken D. J., and McFarland, M., Cambridge University Press, Cambridge, UK, 27-64, 1999.

Dessens, O. and Siomon, P.: The impsortance of dynamics/chemistry coupling in the evaluation of aircraft emissions impact studies, Meteorol. Zeitschrift, 11, 161-175, 2002.

Fichter, C., Marquart, S., Sausen, R., and Lee, D. S.: The impact of cruise altitude on contrails and related radiative forcing, Meteorol. Zeitschrift, 14, 563-572, 2005.

Forster, P. M. D. and Shine, K. P.: Radiative forcing and temperature trends from stratospheric ozone changes, J. Geophys. Res.-Atmos., 102, 10841-10 855, 1997.

Forster, P. M., Shine, K. P., and Stuber, N.: It is premature to include non-CO2 effects of aviation in emission trading schemes, Atmos. Env., 40, 1117-1121, 2006.

Fouquart, Y. and Bonel, B.: Computations of solar heating of the earth's atmosphere: a new

TRADEOFFs in climate effects

through aircraft routing

F. Stordal et al.

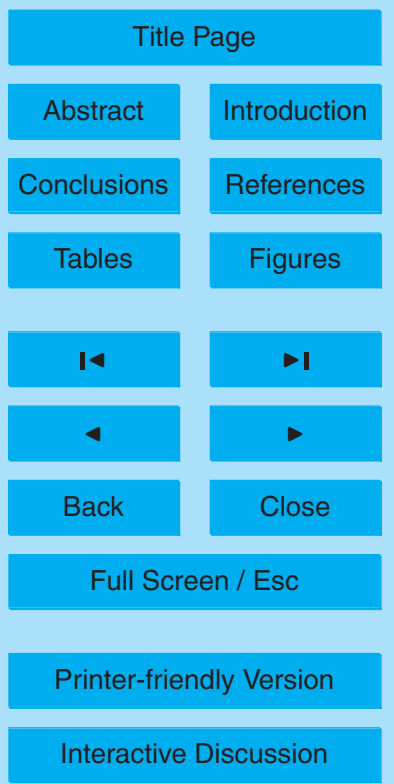


parameterization, Beitr. Phys. Atmos., 53, 35-62, 1980.

Gauss, M., Isaksen, I. S. A., Wong, S., and Wang, W.-C.: Impact of $\mathrm{H} 2 \mathrm{O}$ emissions from cryoplanes and kerosene aircraft on the atmosphere, J.Geophys. Res., 108(D10), 4304, doi:10.1029/2002JD002623, 2003.

5 Gauss, M., Myhre, G., Isaksen, I. S. A., Grewe, V., Pitari, G., Wild, O., Collins, W. J., Dentener, F. J., Ellingsen, K., Gohar, L. K., Hauglustaine, D. A., lachetti, D., Lamarque, J.-F., Mancini, E., Mickley, L. J., Prather, M. J., Pyle, J. A., Sanderson, M. G., Shine, K. P., Stevenson, D. S., Sudo, K., Szopa, S., and Zeng, G.: Radiative forcing since preindustrial times due to ozone change in the troposphere and the lower stratosphere, Atmos. Chem. Phys., 6, 575-599, 102006

Giannakopoulos, C., Chipperfield, M. P., Law, K. S., and Pyle, J. A.: Validation and intercomparison of wet and dry deposition schemes using ${ }^{210} \mathrm{~Pb}$ in a global three-dimensional off-line chemical transport model. J. Geophys. Res., 104(D19), 23 761-23 784, 1999.

Green, J. E.: Civil aviation and the environmental challenge, Aeronaut. J., 107, 1072, 281-300, 2003.

Green, J. E.: Future aircraft - greener by design? Meteorol. Zeitschrift., 14, 583-590, 2005.

Grewe, V., Reithmeier, C., and Shindell, D. T.: Dynamic-chemical coupling of the upper troposphere and lower stratosphere region, Chemosphere, 47, 851-861, 2002a.

Grewe, V., Dameris, M., Fichter, C., and Lee, D. S.: Impact of aircraft NOx emissions. Part 2: Effects of lowering the flight altitude, Meteorol. Zeitschrift, 11, 197-205, 2002c.

Grewe, V., Dameris, M., Fichter, C., and Sausen, R.: Impact of aircraft $\mathrm{NO}_{\mathrm{x}}$ emissions. Part 1: Interactively coupled climate-chemistry simulations and sensitivities to climate-chemistry feedback, lightning and model resolution, Meteorol. Zeitschrift, 11, 177-186, 2002b.

Hansen, J., Sato, M., and Ruedy, R.: Radiative forcing and climate response, J. Geophys. Res.-Atmos., 102, 6831-6864, 1997.

Hauglustaine, D. A., Hourdin, F., Walters, S., Jourdain, L., Filiberti, M.-A., Larmarque, J.-F., and Holland, E. A.: Interactive chemistry in the Laboratoire de Météorologie Dynamique general circulation model : description and background tropospheric chemistry evaluation, J. Geophys. Res., 109, D04314, doi:10.1029/2003JD003957, 2004.

30 Hesstvedt E., Hov, O., and Isaksen, I. S. A.: Quasi steady-state approximation in air pollution modelling: Comparison of two numerical schemes for oxidant prediction, Int. J. Chem. Kinetics, Vol. X, 971-994, 1978.

Holtslag, A. A. M., DrBruijn, E. I. F, and Pan, H.-L.: A High resolution air mass transformation

TRADEOFFs in climate effects

through aircraft routing

F. Stordal et al.

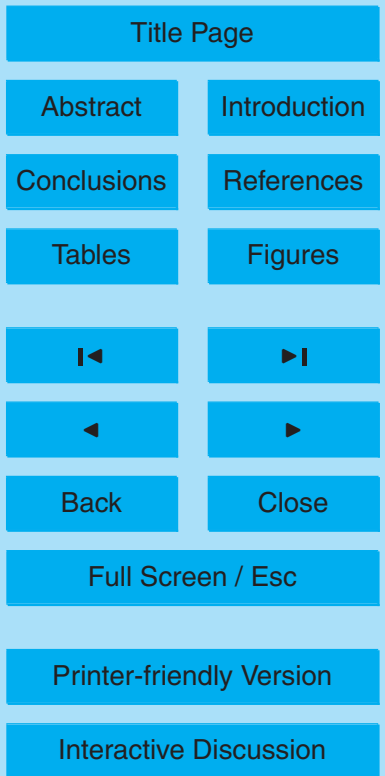


model for short-range weather forecasting, Mon. Wea. Rev., 118, 1561-1575, 1990.

Holtslag, A. A. M and Boville, B. A.:. Local versus non-local boundary layer diffusion in a global climate model, J. Climate, 6(10), 1825-1842, 1993.

Hourdin, F. and Armengaud, A.: The use of finite-volume methods for atmospheric advection of trace species. Part I: test of various formulations in a general circulation model, Mon. Weather Rev., 127, 822-837, 1999.

IPCC: Aviation and the global atmosphere - A special report of IPCC working groups I and III. Intergovernmental Panel on Climate Change, Cambridge University Press, Cambridge, UK and New York, NY, USA, 365 pp., 1999.

10 IPCC: Climate Change 1994 - Radiative Forcing of Climate Change and An Evaluation of the IPCC IS92 SRES Scenarios. Intergovernmental Panel on Climate Change, Cambridge University Press, Cambridge, UK and New York, NY, USA, 339 pp., 1995.

IPCC: Climate Change 2001 - The Scientific Basis. Contributions of working group I to the Third Assessment Report of the Intergovernmental Panel on Climate Change, Cambridge

15 University Press, Cambridge, UK and New York, NY, USA, 881 pp., 2001.

Isaksen, I. S. A., Zerefos, C., Kourtidis, K., Meleti, C., Dalsoren, S. B., Sundet, J. K., Grini, A., Zanis, P., and Balis, D.: Tropospheric ozone changes at unpolluted and semipolluted regions induced by stratospheric ozone changes, J. Geophys. Res., 110(D2), D02302, doi:10.1029/2004JD004618, 2005.

20 Isaksen, I., Jackman, C., Baughcum, S., Dentener, F., Grose, W., Kasibhatla, P., Kinnison, D., Ko, M. K. W., McConnel, J. C., Pitari, G., and Wuebbles, D. J.: Modeling the chemical composition of the future atmosphere, in: Aviation and the Global Atmosphere. A Special Report of IPCC Working Groups I and III, edited by: Penner, J. E., Lister, D. H., Griggs, D. J., Dokken, D. J., and McFarland, M., Cambridge University Press, Cambridge, UK, 121-163, 1999.

Jourdain, L. and Hauglustaine, D. A.: The global distribution of lightning NOx simulated on-line in a general circulation model, Phys. Chem. Earth (C ), 26, 585-591, 2001.

Kraabøl, A. G., Berntsen, T. K., Sundet, J. K, and Stordal, F.: Impact of $\mathrm{NO}_{\mathrm{x}}$ emissions from subsonic aircraft in a global 3D-CTM including plume processes, J. Geophys. Res., 107, 4655, doi:10.1029/2001JD001019, 2002.

Law, K. S. and Pyle, J. A.:. Modeling trace gas budgets in the troposphere, 1, Ozone and odd nitrogen. J. Geophys. Res., 98(D10), 18377-18400, 1993.

Law, K. S., Plantevin, P. H., Shallcross, D. E., Rogers, H. L., and Pyle, J. A.: Evaluation of

TRADEOFFs in climate effects

through aircraft routing

F. Stordal et al.

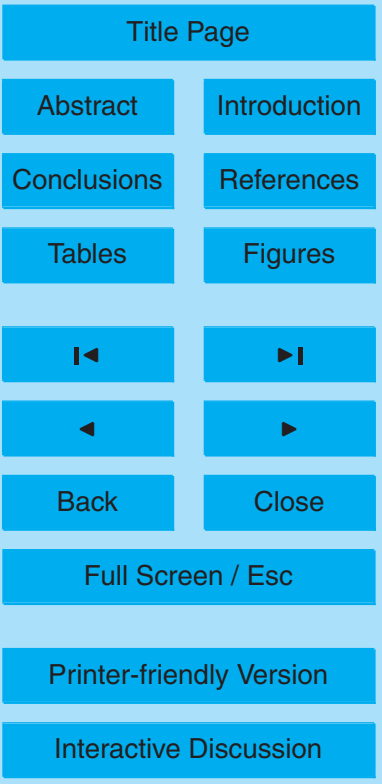


modeled $\mathrm{O} 3$ using Measurements of Ozone by Airbus In-Service Aircraft (MOZAIC) data, J. Geophys. Res., 103(D19), 25 721-25737, 1998.

Law, K. S., Plantevin, P.-H., Thouret, V., Marenco, A., Asman, W. A. H., Lawrence, M., Crutzen, P. J., Muller, J.-F., Hauglustaine, D. A., and Kanakidou, M.: Comparison between global 5 chemistry transport model results and Measurement of Ozone and Water Vapor by Airbus In-Service Aircraft (MOZAIC) data, J. Geophys. Res., 105(D1), 1503-1525, 2000.

Li, D. and Shine, K. P.: A 4-dimensional ozone climatology for UGAMP models, UGAMP Internal reports $n^{\circ} 35,1995$.

Liu, Y., Isaksen, I. S. A., Sundet, J. K., Zhou, X. J., and Ma, J. Z.: Impact of aircraft NOx emissions on $\mathrm{NO}_{x}$ and ozone over China, Adv. Atmos. Sci., 20, 565-574, 2003.

Mannstein, H., Spichtinger, P., and Gierens, K.: A note on how to avoid contrail cirrus, Transportation Res. Part D - Transport and Environment, 10, 421-426, 2005.

Marquart, S., Sausen, R., Ponater, M., and Grewe, V.: Estimate of the climate impact of cryoplanes, Aerospace Sci. Technol., 5, 78-84, 2001.

Morcrette, J.-J.: Radiation and cloud radiative properties in the European Centre for Medium Range Weather Forecasts forecasting system, J. Geophys. Res., 96, 9121-9132, 1991.

Mueller, J.: Geographical distribution and seasonal variation of surface emissions and deposition velocities of atmospheric trace gases, J. Geophys. Res., 97, 3787-3804, 1992.

Myhre, G. and Stordal, F.: On the tradeoff of the solar and thermal infrared radiative impact of contrails, Geophys. Res. Lett., 28, 3119-3122, 2001.

Myhre, G., Highwood, E. J., Shine, K. P., and Stordal, F.: New estimates of radiative forcing due to well mixed greenhouse gases, Geophys. Res. Lett., 25, 2715-2718, 1998.

Myhre, G., Karlsdottir, S., Isaksen, I. S. A., and Stordal, F.: Radiative forcing due to changes in tropospheric ozone in the period 1980 to 1996, J. Geophys. Res.-Atmos., 105, 2893528942, 2000.

Olivier, J. G. J. and Berdowski, J. J. M.: Global emissions sources and sinks. in: "The Climate System",edited by: Berdowski, J., Guicherit, R., and Heij, B. J., pp. 33-78. A.A. Balkema Publishers/Swets \& Zeitlinger Publishers, Lisse, The Netherlands. ISBN 9058092550 , 2001.

30 Olivier, J. G. J., Bouwman, A. F., Berdowski, J. J. M., Veldt, C., Bloos, J. P. J., Visschedijk, A. J. H., van der Maas, C. W. M., and Zasndveld, P. Y. J.: Sectoral emission inventories of greenhouse gases for 1990 on a per country basis as well as on 1x1, Envir. Sci. Policy, 2, 241-263, 1999.

TRADEOFFs in climate effects

through aircraft routing

F. Stordal et al.

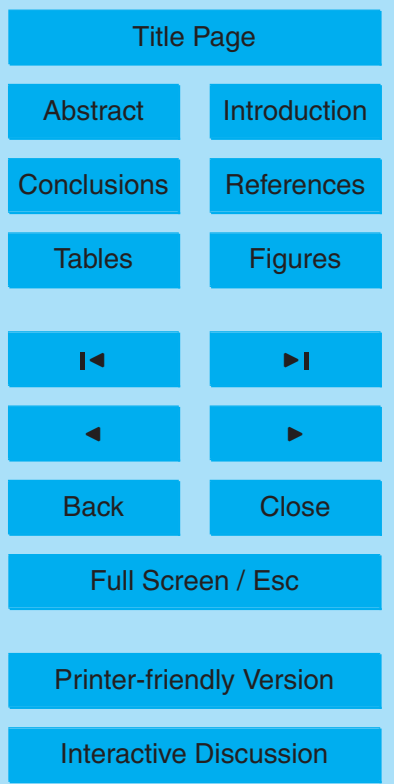

\section{5}


Pitari, G., Mancini, E., Rizi, V., and Shindell, D. T.: Impact of future climate and emission changes on stratospheric aerosols and ozone, J. Atmos. Sci., 59, 414-440, 2002.

Prather, M. J.: Natural modes and timescales in atmospheric chemistry: Theory, GWPs for $\mathrm{CH}_{4}$ and CO, and runaway growth, Geophys. Res. Lett. 23, 2597-2600, 1996.

5 Prather, M. J., Ehhalt, D. H., Dentener, F. J., Derwent, R. G., Dlugokencky, E. J., Holland, E. A., Isaksen, I. S. A., Katima, J., Kirchhoff, V., Matson, P. A., Midgley, P., and Wang, M.: Atmospheric chemistry and greenhouse gases, in: Climate Change 2001: The Scientific Basis. Contribution of Working Group I to the Third Assessment Report of the Intergovernmental Panel on Climate, edited by: Change, J. T., Houghton, Y., Ding, D. J., Griggs, M., Noguer, P. J., van der Linden, X., Dai, K., Maskell, K., and Johnson, C. A., Cambridge University Press, Cambridge, UK, pp. 239-287, 2001.

Prather, M. J.: Numerical advection by conservation of second order moments. J. Geophys. Res., 91(D6), 6671-6681, 1986.

Price, C., Penner, J., and Prather, $\mathrm{M} .: \mathrm{NO}_{x}$ from lightning 1. Global distribution based on light15 ning physics, J. Geophys. Res., 102(D5), 5929-5942, 1997a.

Price, C., Penner, J., and Prather, $\mathrm{M} .: \mathrm{NO}_{\mathrm{x}}$ from lightning 2. Constraints from the global atmospheric circuit, J. Geophys. Res., 102(D5), 5943-5952, $1997 \mathrm{~b}$.

Price, C. and Rind, D.: A simple lightning parameterization for calculating global lightning distributions, J. Geophys. Res., 97(D9), 9919-9933, 1992.

20 Rogers, H. L., Lee, D. S., Raper, D. W., Foster, P. M. D., Wilson, C. W., and Newton, P. J.: The impact of aviation on the atmosphere, Aeronautical J., 106, 521-546, 2002.

Rummukainen, M., Isaksen, I. S. A., Rognerud, B., and Stordal, F.: A global model tool for three-dimensional multiyear stratospheric chemistry simulations: Model description and first results, J. Geophys. Res., 104, 26 437-26 456, 1999.

Sadourny, R. and Laval, K.: January and July performance of the LMD general circulation model, New perspectives in climate modeling, edited by: Berger, A. and Nicolis, C., Elsevier, 173-197, 1984.

Sausen, R., Nodorp, D., Land, C., and Deidewig, F.: Ermittlung optimaler Flughöhen und Flugrouten unter dem Aspekt minimaler Klimawirksamkeit. DLR-Forschungsbericht 96-13, ISSN $30 \quad$ 0939-2963, 105 pp., 1996.

Sausen, R., Isaksen, I. S. A., Grewe, V., Hauglustaine, D., Lee, D. S., Myhre, G., Köhler, M. O., Pitari, G., Schumann, U., Stordal, F., and Zerefos, C.: Aviation Radiative Forcing in 2000: An Update on IPCC (1999), Meteorol. Zeitschrift, 14, 555-561, 2005.

TRADEOFFs in climate effects

through aircraft routing

F. Stordal et al.

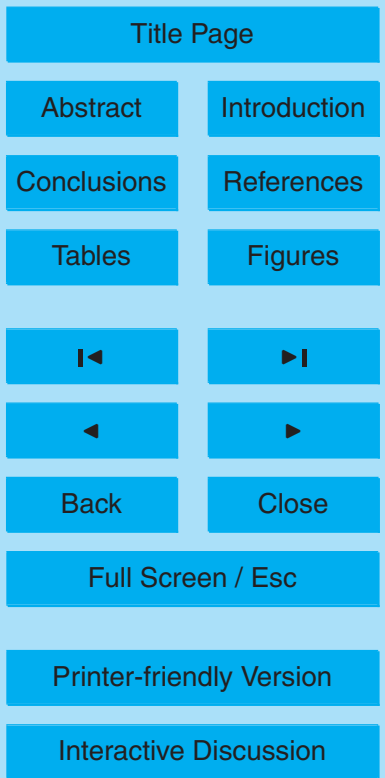


Schumann, U.: Formation, properties and climate effects of contrails, Comptes Rendes Physique, 6, 549-565, 2005.

Stevenson, D. S., Doherty, R. M., Sanderson, M. G., Collins, W. J., Johnson, C. E., and Derwent, R. G.: Radiative forcing from aircraft $\mathrm{NO}_{\mathrm{x}}$ emissions, J. Geophys. Res., 109, D17307, doi:10.1029/2004JD004759, 2004.

Stockwell, D. Z., Giannakopoulos, C., Plantevin, P.-H., Carver, G. D., et al.: Modelling $\mathrm{NO}_{\mathrm{x}}$ from lightning and its impact on global chemical fields. Atmos. Environ., 33(27), 4477-4493, 1999.

Stordal, F., Myhre, G., Arlander, D. W., Svendby, T. E., Stordal, J. G., and Rossow, W. B.: Is there a trend in cirrus cloud cover due to aircraft traffic?, Atmos. Chem. Phys., 5, 2155-2162, 2005.

Stuber, N., Forster, P., Rädel, G., and Shine, K.: The importance of the diurnal and annual cycle of air trafiic for contrail radiative forcing, Nature, 441, 864-867, doi:10.1038/nature04877, 2006.

Svensson, F., Hasseltrot, A., and Moldanova, J.: Reduced environmental impact by lowered cruise altitude for liquid hydrogen-fuelled aircraft, Aerospace Sci. Technol., 8(4), 307-320, 2004.

Tiedtke, M.: A comprehensive mass flux scheme for cumulus parameterization in large-scale models, Mon. Wea. Rev., 117(8), 1779-1800, 1989.

20 Van Leer, B.: Towards ultimate conservative difference scheme, Part IV: A new approach to numerical convection, J. Comput. Phys., 23, 276-299, 1977.

Wang, K.-Y., Pyle, J. A., Sanderson, M. G., and Bridgeman, C.: Implementaion of a convective atmospheric boundary layer scheme in a tropospheric chemistry transport model, J. Geophys. Res., 104(D19), 23 729-23745, 1999.

Weseley, M. L.: Parameterization of surface resistances to gaseous dry deposition in regionalscale numerical models, Atmos. Environ., 23, 1293-1304, 1989.

Wild, O., Zhu, X., and Prather, M. J.: Fast-J: Accurate Simulation of In- and Below cloud Photolysis in Tropospheric Chemical Models, J. Atmos. Chem., 37(3), 245-282, 2000.

Wild, O. and Prather, M. J.: Excitation of the primary tropospheric chemical mode in a global three-dimensional model, J. Geophys. Res., 105, 24647-24660, 2000.

Williams, V., Noland, R. B., and Tuomi, R.: Air transport cruise altitude restrictions to minimalize contrail formation, Climate Policy, 3, 207-219, 2003.

Williams, V., Noland, R. B., and Tuomi, R.: Reducing the climate change impacts of aviation

TRADEOFFs in climate effects

through aircraft routing

F. Stordal et al.

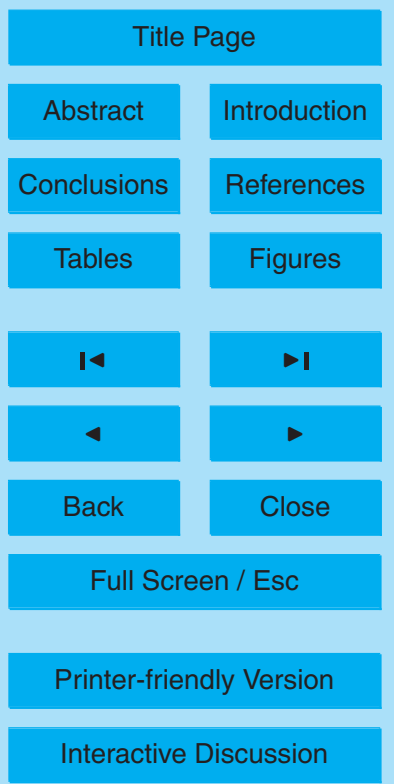


by restricting cruise altitudes, Transportation Res. Part D - Transport and Environment, 7, 451-464, 2002.

\section{ACPD}

6, 10733-10771, 2006

\section{TRADEOFFs in} climate effects through aircraft routing

F. Stordal et al.

Title Page

Conclusions

References

Tables

Figures

14

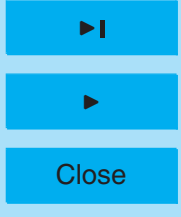

Back

Full Screen / Esc

Printer-friendly Version

Interactive Discussion 


\section{ACPD}

6, 10733-10771, 2006

Table 1. Summary of the model simulations and TRADEOFF aircraft emission scenarios used in this work. The scenarios are a subset of those used and further explained and investigated in Gauss et al. (2005).

\begin{tabular}{|c|c|c|c|c|}
\hline Model run & Aircraft emission scenario used & Fuel burn Tg/year & Total nitrogen emission ${ }^{1)} \mathrm{Tg}(\mathrm{N}) /$ year & $\begin{array}{l}\text { E.I. }\left(\mathrm{NO}_{x}\right) \\
\text { fleet average }\end{array}$ \\
\hline no_air & no aircraft & - & - & - \\
\hline base & base case & 152 & $0.594(16.9 \%)$ & 12.9 \\
\hline pol_norm & $\begin{array}{l}\text { additional polar routes, } \\
\text { normalized }^{3)}\end{array}$ & 152 & $0.594(34.1 \%)$ & 12.9 \\
\hline low_adj & $\begin{array}{l}\text { lower cruise altitude }(-6000 \mathrm{ft}) \text {, } \\
\text { changed fuel burn }{ }^{3)}\end{array}$ & 161 & $0.620(5.8 \%)$ & 12.7 \\
\hline high_adj & $\begin{array}{l}\text { higher cruise altitude }(+2000 \mathrm{ft}) \text {, } \\
\text { changed fuel burn }{ }^{3)}\end{array}$ & 151 & $0.604(20.0 \%)$ & 13.1 \\
\hline
\end{tabular}

1) The fraction of aircraft emissions occurring in the stratosphere is given in parenthesis.

2) The $\mathrm{NO}_{\mathrm{x}}$ emission index, E.I. $\left(\mathrm{NO}_{\mathrm{x}}\right)$, is defined as grams of $\mathrm{NO}_{\mathrm{x}}\left(\right.$ as $\left.\mathrm{NO}_{2}\right)$ emitted per $\mathrm{kg}$ of burnt fuel.

3) Changes in flight routing will in general imply changes in fuel burn. In the "adjusted fuel burn" cases this effect is taken into account, while the "normalized" scenario uses the same total fuel burn as in the base case.

\section{TRADEOFFs in climate effects through aircraft routing}

F. Stordal et al.

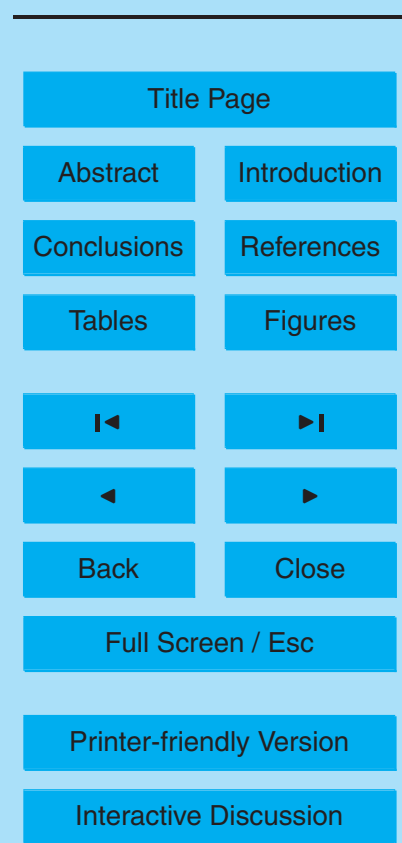




\section{ACPD}

6, 10733-10771, 2006

\section{TRADEOFFs in climate effects \\ through aircraft routing}

Table 2. Change in global ozone (DU) due to aircraft. Results are given for current (2000) conditions (base case) as well as three cases of changes in aircraft routing (34 DU=370 Tg).

\begin{tabular}{llllll}
\hline Case & Difference & Oslo CTM2 & LMDz/INCA & TOMCAT & ULAQ \\
\hline Base case & base - no_air & +0.338 & +0.445 & +0.308 & +0.328 \\
Add polar routes & pol_norm - base & -0.0089 & & & -0.0467 \\
Lower cruise alt & low_adj - base & -0.0136 & -0.0429 & -0.0404 & +0.0365 \\
Higher cruise alt & high_adj - base & +0.0157 & +0.0271 & +0.0193 & +0.0172 \\
\hline
\end{tabular}

F. Stordal et al.

Title Page

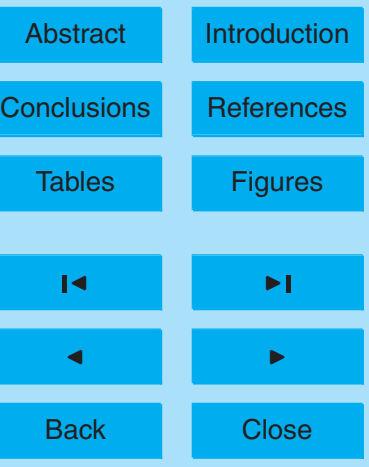

Full Screen / Esc

Printer-friendly Version

Interactive Discussion 


\section{ACPD}

6, 10733-10771, 2006

\section{TRADEOFFs in climate effects \\ through aircraft routing}

Table 3. As for Table 1, but for global methane lifetime (\%). Feedback mechanisms are not taken into account in the numbers given in this table.

\begin{tabular}{lllllll}
\hline Case & Difference & Oslo CTM2 & LMDz/INCA & TOMCAT & ULAQ & Average \\
\hline Base case & base - no_air & -0.71 & -1.31 & -1.59 & -0.69 & -1.08 \\
Add polar routes & pol_norm - base & +0.11 & & & +0.08 & \\
Lower cruise alt & low_adj - base & -0.15 & -0.02 & -0.09 & -0.35 & -0.15 \\
Higher cruise alt & high_adj - base & +0.00 & -0.05 & -0.04 & +0.01 & -0.02 \\
\hline
\end{tabular}

F. Stordal et al.

Title Page

Abstract

Conclusions

Tables

14

4

Back
Introduction

References

Figures

$\rightarrow$

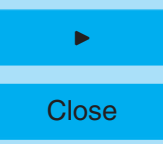

Full Screen / Esc

Printer-friendly Version

Interactive Discussion 


\section{ACPD}

6, 10733-10771, 2006

\section{TRADEOFFs in climate effects \\ through aircraft routing}

Table 4. Global radiative forcing $\left(\mathrm{mWm}^{-2}\right)$ due to short-term increase of ozone from aircraft. Results are given for current aircraft (base case) as well as three cases of changes in aircraft routing.

\begin{tabular}{llllll}
\hline Case & Difference & Oslo CTM2 & LMDz/INCA & ULAQ & Average \\
\hline Base case & base - no_air & +10.84 & +15.92 & +16.10 & 14.29 \\
Add polar routes & pol_norm - base & -0.35 & & -1.45 & \\
Lower cruise alt & low_adj - base & -1.21 & -1.82 & +1.45 & -0.53 \\
Higher cruise alt & high_adj - base & +0.68 & +1.07 & +0.47 & +0.74 \\
\hline
\end{tabular}

F. Stordal et al.

Title Page

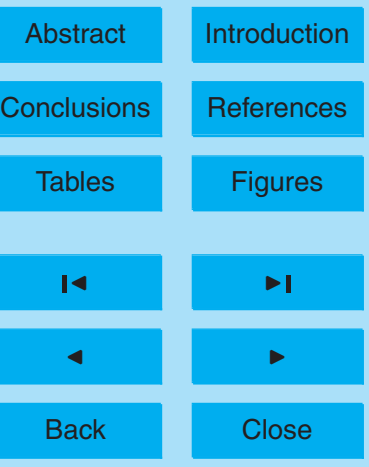

Full Screen / Esc

Printer-friendly Version

Interactive Discussion 


\section{ACPD}

6, 10733-10771, 2006

Table 5. Global radiative forcing $\left(\mathrm{mWm}^{-2}\right)$ due to methane resulting from aircraft. Results are given for current aircraft (base case) as well as three cases of changes in aircraft routing. Results are based on changes in methane lifetime corrected for feedback mechanisms (see text for further details), and on an analytical relation between methane changes and the radiative forcing from IPCC (2001).

\begin{tabular}{lllllll}
\hline Case & Difference & Oslo CTM2 & LMDz/INCA & TOMCAT & ULAQ & Average \\
\hline Base case & base - no_air & -6.4 & -11.9 & -14.4 & -6.3 & -9.8 \\
Add polar routes & pol_norm - base & +0.99 & & & +0.73 & \\
Lower cruise alt & low_adj - base & -1.34 & -0.15 & -0.84 & -3.17 & -1.38 \\
Higher cruise alt & high_adj - base & +0.03 & -0.48 & -0.38 & +0.09 & -0.19 \\
\hline
\end{tabular}

\section{TRADEOFFs in climate effects \\ through aircraft routing}

F. Stordal et al.

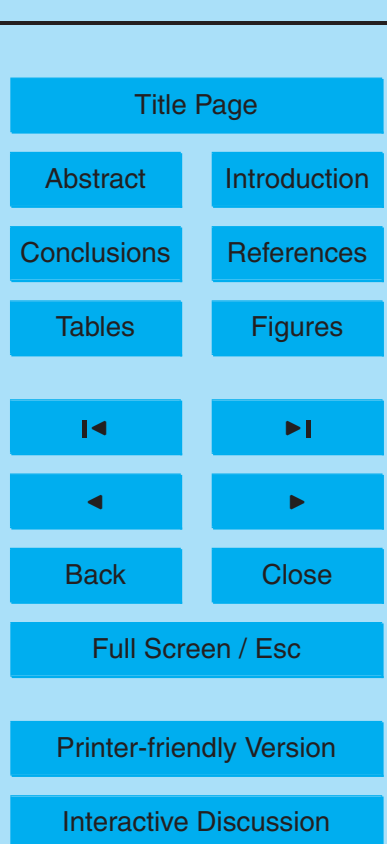




\section{ACPD}

6, 10733-10771, 2006

\section{TRADEOFFs in climate effects \\ through aircraft routing}

Table 6. Global radiative forcing $\left(\mathrm{mWm}^{-2}\right)$ due to $\mathrm{CO}_{2}$ resulting from aircraft. Results are given for current aircraft (base case) as well as three cases of changes in aircraft routing (see text for details).

\begin{tabular}{lll}
\hline Case & Difference & Forcing \\
\hline Base case & base - no_air & 21.7 \\
Add polar routes & pol_norm - base & 0.00 \\
Lower cruise alt & low_adj - base & 1.27 \\
Higher cruise alt & high_adj - base & -0.11 \\
\hline
\end{tabular}

F. Stordal et al.

Title Page

Abstract Introduction

Conclusions References

Tables Figures

14

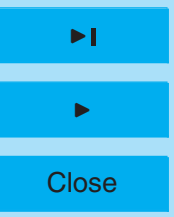

Back

Full Screen / Esc

Printer-friendly Version

Interactive Discussion 


\section{ACPD}

6, 10733-10771, 2006

Table 7. Global radiative forcing $\left(\mathrm{mWm}^{-2}\right)$ due to $\mathrm{O}_{3}, \mathrm{CH}_{4}$ and $\mathrm{CO}_{2}$ resulting from aircraft, summarising the results in Tables $3-5$. Results are given as ranges (encompassing individual models) for current aircraft (base case) as well as three cases of changes in aircraft routing. The total effect is also given for each of there models individually.

\begin{tabular}{|c|c|c|c|c|c|c|}
\hline Case & Difference & $\begin{array}{l}\mathrm{O}_{3} \\
\text { (Short- } \\
\text { term) }\end{array}$ & $\begin{array}{l}\mathrm{O}_{3}(\text { primary } \\
\text { mode) }\end{array}$ & $\mathrm{CH}_{4}$ & $\mathrm{CO}_{2}$ & $\begin{array}{l}\text { Total } \\
\text { OsloCTM2,LMDz/INCA,ULAQ }\end{array}$ \\
\hline Base case & base - no_air & $\begin{array}{l}+10.8 \\
\text { to }+16.1\end{array}$ & $\begin{array}{l}-2.6 \\
\text { to }-6.0\end{array}$ & $\begin{array}{l}-6.3 \\
\text { to }-14.4\end{array}$ & 21.7 & $+23.5,+20.8,+28.9$ \\
\hline Add polar routes & pol_norm - base & $\begin{array}{l}-0.35 \\
\text { to }-1.45\end{array}$ & $\begin{array}{l}+0.30 \\
\text { to }+0.41\end{array}$ & $\begin{array}{l}+0.73 \\
\text { to }+0.99\end{array}$ & 0.00 & $+1.05, \mathrm{NA},-0.42$ \\
\hline Lower cruise alt & low_adj - base & $\begin{array}{l}-1.82 \\
\text { to }+1.45\end{array}$ & $\begin{array}{l}-0.06 \\
\text { to }-1.31\end{array}$ & $\begin{array}{l}-0.15 \\
\text { to }-3.17\end{array}$ & 1.27 & $-1.83,-0.76,-1.76$ \\
\hline Higher cruise alt & high_adj - base & $\begin{array}{l}+0.47 \\
\text { to } 1.07\end{array}$ & $\begin{array}{l}-0.20 \\
\text { to }+0.04\end{array}$ & $\begin{array}{l}-0.48 \\
\text { to }+0.09\end{array}$ & -0.11 & $0.61,0.28,0.49$ \\
\hline
\end{tabular}

TRADEOFFs in climate effects through aircraft routing

F. Stordal et al.

Title Page

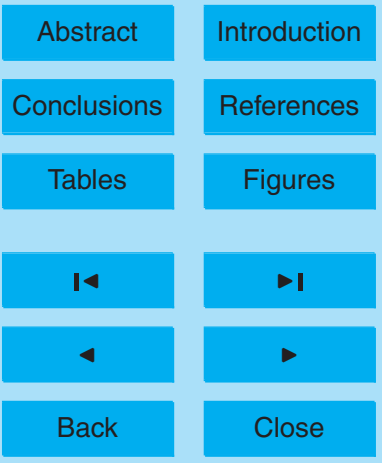

Full Screen / Esc

Printer-friendly Version

Interactive Discussion 


\section{ACPD}

6, 10733-10771, 2006

\section{TRADEOFFs in climate effects \\ through aircraft routing}

Table 8a. Integrated global radiative forcing over a 20 year time horizon due to $\mathrm{O}_{3}$ (short term plus primary mode), $\mathrm{CH}_{4}$ and $\mathrm{CO}_{2}$. Results are given for current aircraft (base case) as well as two cases of changes in aircraft routing and are given in $\mathrm{mWm}^{-2} \mathrm{yr}$ (in per cent of the base case $\mathrm{CO}_{2}$ contribution in parentheses).

\begin{tabular}{llllll}
\hline Case & Difference & $\mathrm{O}_{3}$ & $\mathrm{CH}_{4}$ & $\mathrm{CO}_{2}$ & Total \\
\hline Base case & base - no_air & $+251(144)$ & $-82.8(-47.6)$ & $+174(+100.0)$ & $+342(+197)$ \\
Lower cruise alt & low_adj - base & $-17.3(-10.0)$ & $-11.7(-6.7)$ & $+11.1(+6.4)$ & $-17.9(-10.3)$ \\
Higher cruise alt & high_adj - base & $+14.3(+8.3)$ & $-1.6(-0.9)$ & $-0.9(-0.5)$ & $+11.8(+6.8)$ \\
\hline
\end{tabular}

F. Stordal et al.

Title Page

Abstract

Conclusions

Tables

14

4

Back
Introduction

References

Figures

$\rightarrow$

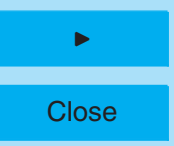

Full Screen / Esc

Printer-friendly Version

Interactive Discussion 


\section{ACPD}

6, 10733-10771, 2006

\section{TRADEOFFs in climate effects \\ through aircraft routing}

F. Stordal et al.

Table 8b. As Table 8a, but for 100 yr time horizon.

\begin{tabular}{llllll}
\hline Case & Difference & $\mathrm{O}_{3}$ & $\mathrm{CH}_{4}$ & $\mathrm{CO}_{2}$ & Total \\
\hline Base case & base - no_air & $+1130(+39.0)$ & $-641(-22.0)$ & $+2920(+100.0)$ & $+3410(+117.0)$ \\
Lower cruise alt & low_adj - base & $-110(-3.8)$ & $-90.1(-3.1)$ & $+187(+6.4)$ & $-13.5(-0.5)$ \\
Higher cruise alt & high_adj - base & $+70.0(+2.4)$ & $-12.1(-0.4)$ & $-15.2(-0.5)$ & $+42.7(+1.5)$ \\
\hline
\end{tabular}

Title Page

Abstract

Conclusions

Tables

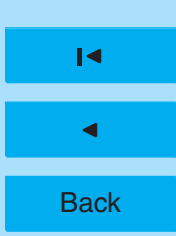

Full Screen / Esc

Printer-friendly Version 


\section{ACPD}

6, 10733-10771, 2006
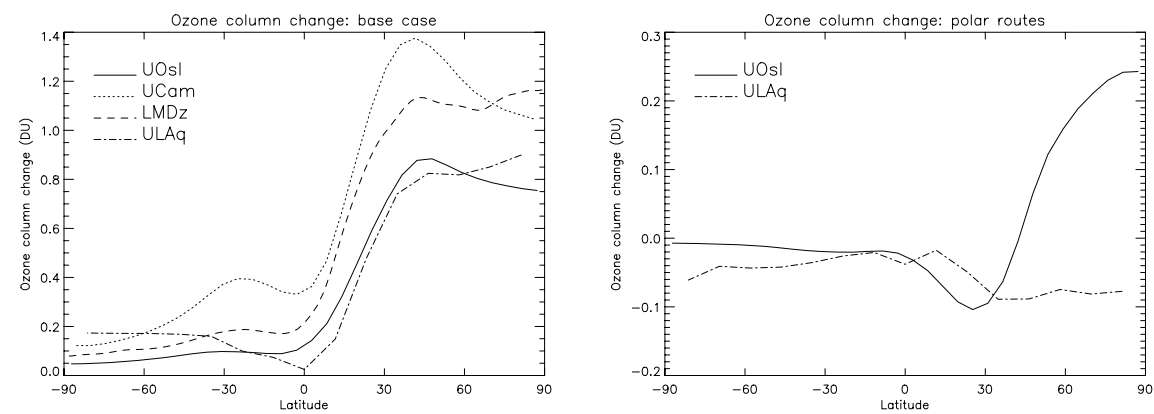

\section{TRADEOFFs in climate effects through aircraft routing}

F. Stordal et al.
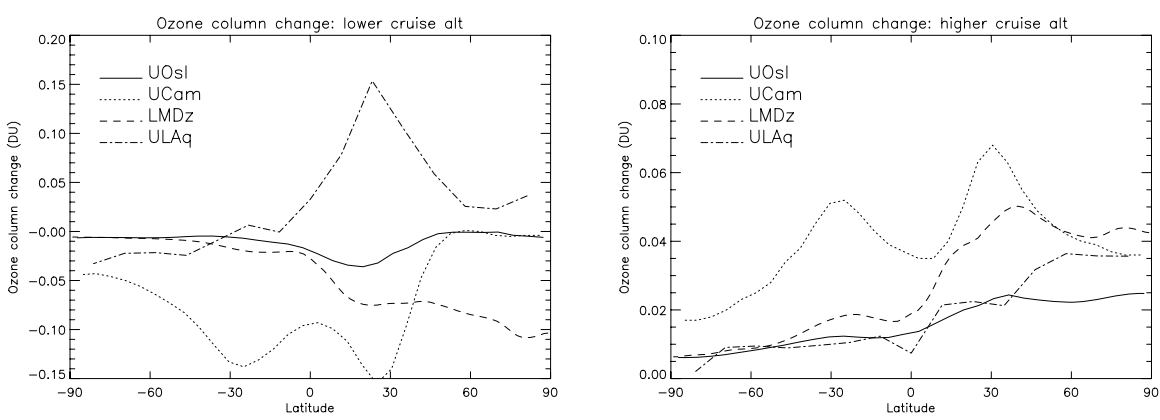

Title Page

Abstract

Conclusions
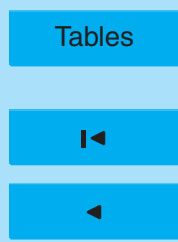

Back
Introduction

References

Figures

-

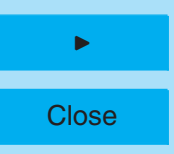

Full Screen / Esc

Printer-friendly Version
Fig. 1. Zonally and yearly averaged ozone column change (DU) due to aircraft as a function of latitude; upper left) base case, upper right) additional polar routes, lower left) lower cruise altitude, and lower right) higher cruise altitude. 


\section{ACPD}

6, 10733-10771, 2006
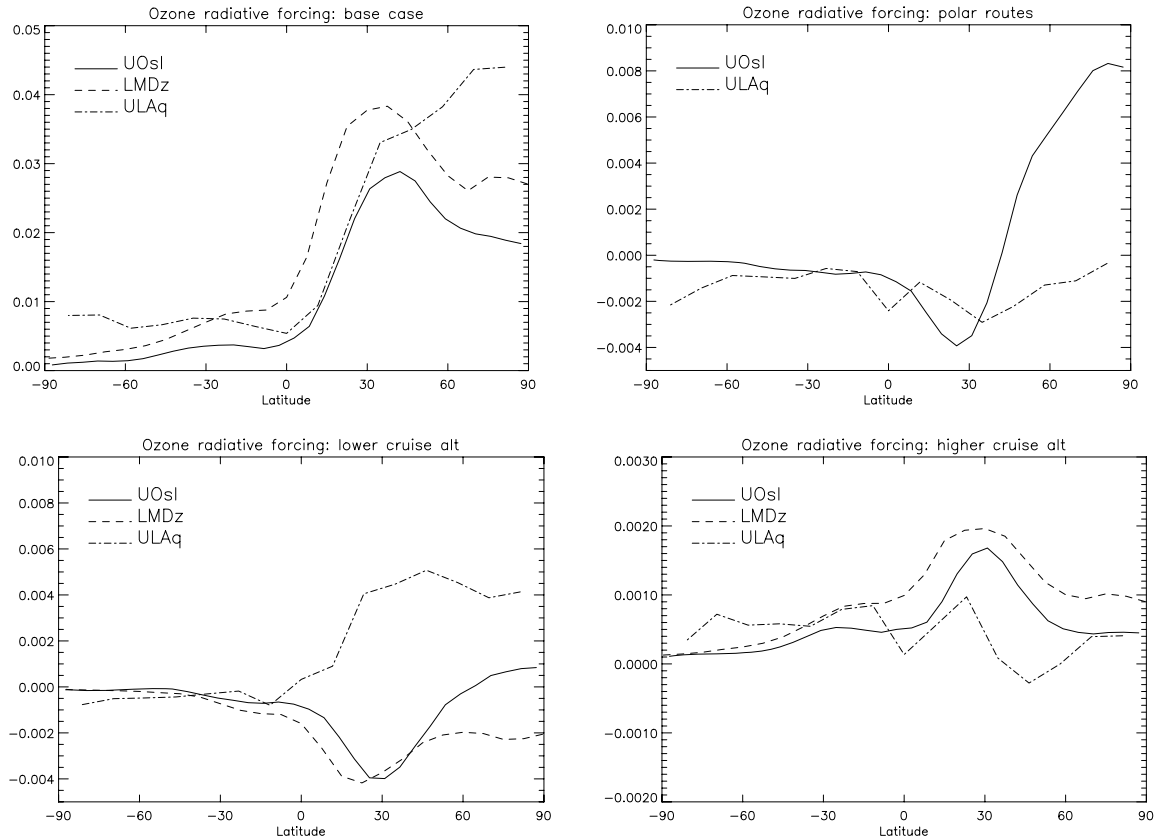

Fig. 2. Zonally and yearly averaged radiative forcing $\left(\mathrm{Wm}^{-2}\right)$ due ozone resulting from aircraft as a function of latitude; upper left) base case, upper right) additional polar routes, lower left) lower cruise altitude, and lower right) higher cruise altitude.

Title Page

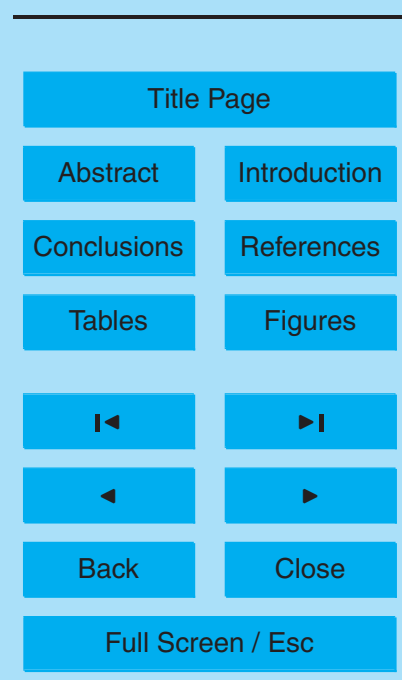

Full Screen / Esc

TRADEOFFs in climate effects through aircraft routing

F. Stordal et al.

Printer-friendly Version

Interactive Discussion 
Ozone column change: polar routes
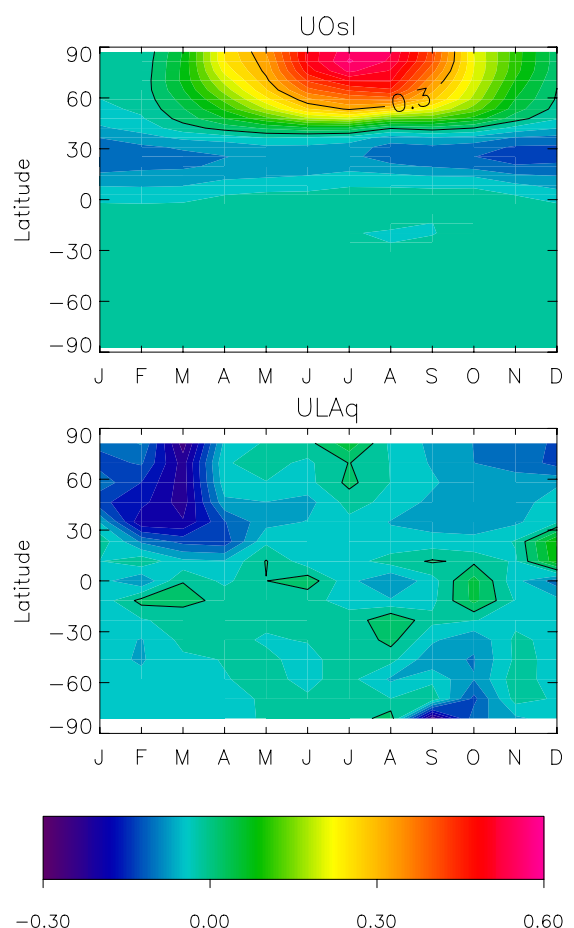

Ozone radiative forcing: polar routes
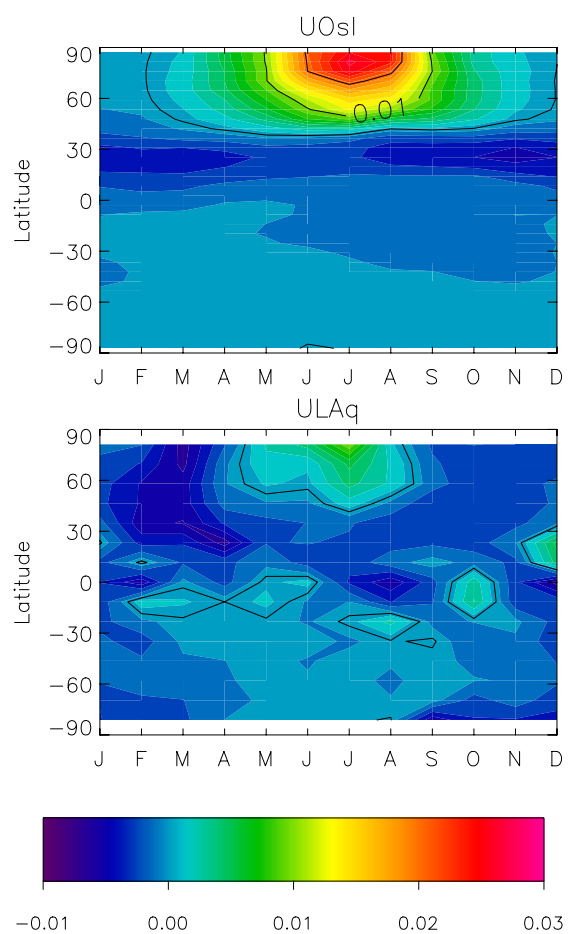

\section{ACPD}

6, 10733-10771, 2006

TRADEOFFs in climate effects through aircraft routing

F. Stordal et al.

Title Page

Abstract

Conclusions

Tables

14

4

Back
Introduction

References

Figures

$>1$

$>$

Close

Full Screen / Esc

Fig. 3. Zonally averaged changes in (left) ozone column (DU) and (right) radiative forcing $\left(\mathrm{Wm}^{-2}\right)$ due ozone resulting from aircraft as a function of latitude and season in the case of additional polar routes.

Printer-friendly Version

Interactive Discussion 

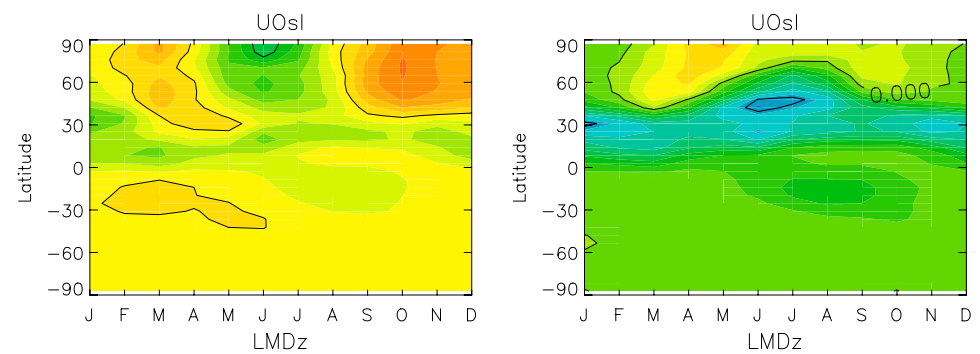

6, 10733-10771, 2006
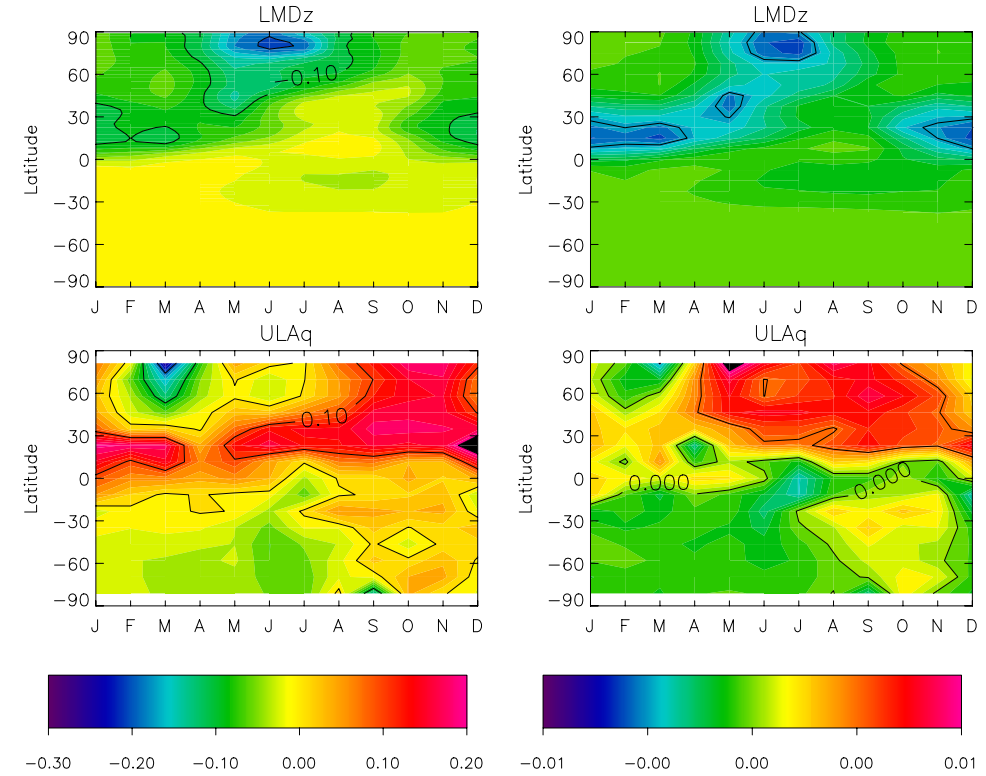

TRADEOFFs in climate effects through aircraft routing

F. Stordal et al.

Title Page

Abstract

Conclusions

Tables

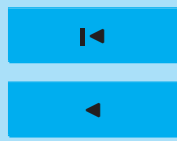

Back
Introduction

References

Figures

$>1$

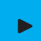

Close

Full Screen / Esc

Printer-friendly Version

Interactive Discussion

Fig. 4. Zonally averaged changes in (left) ozone column (DU) and (right) radiative forcing Interactive Discussion lower cruise altitude. 